\title{
TROGIRSKI PLEMIĆI MICHIELI VITTURI - VISOKI ČASNICI MLETAČKIH PREKOMORSKIH KOPNENIH POSTROJBI U DRUGOJ POLOVICI 18. STOLJEĆA*
}

\author{
Lovorka ČORALIĆ \\ Hrvatski institut za povijest \\ Zagreb, Hrvatska \\ Nikola MARKULIN \\ Zadar, Hrvatska
}

\author{
UDK: 94(450 Venecija)“17“: 356: 929 Michieli Vitturi \\ DOI: https://dx.doi.org/10.21857/y6zolb86gm \\ Izvorni znanstveni rad \\ Prihvaćeno: 18. prosinca 2018.
}

Autori u radu, na temelju izvorne građe, rekonstruiraju vojnu karijeru trojice članova trogirske plemićke obitelji Michieli Vitturi (pukovnika Vicka, potpukovnika Nikole te kapetana Jerolima Franju), časnika mletačkih profesionalnih prekomorskih pješačkih postrojbi Oltramarina. U prvom dijelu rada autori nastoje, prateći vojne karijere spomenutih časnika, uočiti i objasniti neke promjene u organizacijskoj strukturi mletačke vojske posljednjih godina postojanja Mletačke Republike. Ponajprije je riječ o promjenama proizašlima iz potrebe Republike da jačanjem svoje vojske zaštiti vlastitu neutralnost i talijanske granice od prijetećih vojski europskih sila sukobljenih u Revolucionarnim ratovima. U drugom dijelu rada donosi se struktura pukovnija, odnosno satnija kojima su spomenuti časnici zapovijedali. Naglasak je pritom upravljen na zavičajno podrijetlo časnika, dočasnika i običnih vojnika koji su popisani od strane mletačke državne magistrature za novačenja (Inquisitori sopra l'amministrazione dei pubblici ruoli) te se $s$ tim ciljem donosi više grafičkih prikaza udjela pojedinih regija (ponajprije su to one na istočnojadranskim mletačkim stečevinama) u istraživanim satnijama, a na kraju rada objavljuje nekoliko popisa vojnog ljudstva satnija rečene trojice mletačkih časnika iz obitelji Michieli Vitturi.

Ključne riječi: obitelj Michieli Vitturi, Mletačka Republika, Oltramarini, cernide, vojna povijest, povijest 18. stoljeća.

\section{UVODNE NAPOMENE: MLETAČKA VOJNA ORGANIZACIJA U DRUGOJ POLOVICI 18. STOLJEĆA}

Usprkos tomu što je svoj posljednji rat završila 1718. godine, Mletačka je vojska u posljednjim desetljećima 18. stoljeća zadržala osnovne organizacijske strukture oblikovane $u$ vrijeme dva posljednja rata protiv Osmanskog Carstva - Morejskom ratu i Drugom morejskom ratu. Povremeni reformni zahvati, od kojih su oni vođeni dvadesetih godina pod nadzorom maršala Matthiasa von der Schulenburga bili najopsežniji, u prvom su redu ciljali na smanjivanje državnih troškova za vojsku. No, slično se stanje može pratiti i u ostalim europskim

\footnotetext{
* Ovaj rad je sufinancirala Hrvatska zaklada za znanost projektom broj 3675
} 
državama 18. stoljeća gdje su povremene taktičke i tehnološke inovacije uklapane u postojeće vojne organizacijske strukture. Sveobuhvatne promjene nastupit će tek s Ratovima francuske revolucije. ${ }^{1}$

Nakon završetka svog posljednjeg rata 1718. godine, Mletačka Republika smanjila je svoje vojne snage, a sličnim je postupcima pribjegavala i u prošlosti nakon što bi bili potpisani mirovni ugovori (primjerice 1669. i 1699. godine). No, europska je povijest 18. stoljeća bila obilježena gotovo neprekinutim ratovima velikih sila, a budući da je sjeverna Italija zbog svog geostrateškog položaja i bogatstva resursa potrebnih za uzdržavanje vojski često bila glavno poprište ratnih operacija velikih europskih sila, Republika je bila prisiljena štititi svoje granice i svoju neutralnost. U tim bi razdobljima na svojim talijanskim posjedima rasporedila svoje najbolje profesionalne postrojbe, dok bi u međuvremenu državna administracija ugovorila novačenje novih pukovnija. Kao pomoćnu snagu svojoj profesionalnoj vojsci Republika je mobilizirala i teritorijalnu miliciju (ordinanze, cernide, colletizie i krajine) te bi, usprkos tomu što bi moral ovih postrojbi znatno opadao kako bi se vojnici udaljavali od svog zavičaja, iz Dalmacije u Italiju, sistemom rotacije, pozivala postrojbe lokalnih cernida i krajini. ${ }^{2}$

Prilično dobar uvid u veličinu kopnene vojske Republike pruža jedan plan o načinu rotiranja njezinih postrojbi na trima područjima (riparto) - Italiji, Levantu i Dalmaciji - iz 1783. godine. Plan je predviđao rotaciju postrojbi u razdoblju od 1785. do 1796. godine, a prema njemu Republika je početkom osamdesetih godina imala 12 topničkih satnija, 11 pješačkih pukovnija Oltramarina i 18 talijanskih pješačkih pukovnija (Reggimenti Italiani). ${ }^{3} \mathrm{U}$ ovo su vrijeme pješačke pukovnije mletačke vojske nominalno imale otprilike od 500 do 1000 ljudi, s time da je stvarno stanje postrojbi nerijetko znalo odstupati i za jednu trećinu, a treba napomenuti kako plan nije obuhvaćao konjaničke pukovnije kojih je Republika u 18. stoljeću znala imati desetak.

1 Jermy BLACK, European Warfare, 1660-1815, London, 1994.; J. BLACK, Warfare in the Eighteenth Century, London, 1999.; Christopher DufFy, The Military Experience in the Age of Reason, LondonNew York, 2005.; David ChandLer, The Art of Warfare in the Age of Marlborough, Kent, 1990.

2 Za takve postupke u vrijeme Rata za španjolsku baštinu vidi: Nikola MARKULIN, Vojno poduzetništvo u Mletačkoj Dalmaciji i Boki od 1700. do 1718. godine, Povijesni prilozi, god. 35, sv. 51, Zagreb, 2016., 159 - 196; Nikola MARKULIN, Mletačka organizacija teritorijalnih vojnih postrojbi u Dalmaciji od 1684. do 1718. godine, Radovi Zavoda za povijesne znanosti HAZU u Zadru, br. 59, Zadar, 2017., 251 - 287. Za dodatna novačenja u vrijeme Rata za poljsku baštinu i Rata za austrijsku baštinu vidi Lovorka ČoraLIĆ - Nikola MAR KULIN, Kotorski plemić Benedikt Paskvali (1704. - 1790.) - zapovjednik mletačkih prekomorskih kopnenih postrojbi, Acta Histriae, 2018. (u postupku objavljivanja).

3 Terminazione...per la Circolazione de' Reggimenti d' Infanteria Italiani, ed Oltramarini, e delle Compagnie d' Artiglieri (26. veljače 1783.) Državni arhiv u Zadru (dalje: HR-DAZD), fond 386, Zbirka tiskovina/stampata 1608. - 1959., kutija 4., sign. 2., bez paginacije. 
Iako je državna administracija u 18. stoljeću nastojala učvrstiti svoju kontrolu nad profesionalnim postrojbama, one su još uvijek bile novačene i organizirane suradnjom države i vojnih poduzetnika. ${ }^{4}$ Mletačka je Republika od 16. stoljeća znatan dio svojih profesionalnih vojnika novačila na svojim istočnojadranskim posjedima (Istra, Kvarner, Dalmacija i Boka) i u njihovu neposrednom zaleđu, a od sredine 17. stoljeća za takve se pješačke postrojbe ustalio naziv Oltramarini, dok su konjaničke postrojbe nazivane Croati a cavallo. U njihovu se novačenju i organiziranju državna administracija oslanjala na široko rasprostranjenu i dobro organiziranu mrežu vojnih poduzetnika koji su mahom dolazili iz redova društvenih elita tih prostora. Bili su to najčešće plemići dalmatinskih i bokeljskih komuna, pripadnici bogatih građanskih obitelji, kao i elite brojnih zajednica koje su u jeku posljednja dva rata protiv Osmanskog Carstva prešle na mletačku stranu. Nerijetko su se takve aktivnosti prenosile s generacije na generaciju pripadnika pojedine obitelji, pa je do sredine 18. stoljeća formirana prava časnička kasta dalmatinskih i bokeljskih elita. Jedna od značajnijih posljedica ove pojave bilo je čvrsto povezivanje i ispreplitanje interesa lokalnih elita s interesima središnje vlasti.

Među istaknutim časnicima mletačkih prekomorskih postrojbi od sredine 17. stoljeća pa do duboko u 18. stoljeće ističu se pripadnici vodećih gradskih plemićkih obitelji - zadarske Fanfonja (Fanfogna), Benja (Begna), Detriko (Detrico) i Nassi, šibenske Divnić (Difnico), Fenzi, Filiberi i Zavorović (Zavoreo), potom Kaštelani pučkog podrijetla iz obitelji Kumbat (Cumbat, Combat). Iz Boke su se, primjerice, izdvajali časnici iz obitelji Bolica (Bolizza), Buća (Bucchia), Gregorina, Paskvali (Pasquali), Štukanović, Visković, Vraćen (Vrachien), ali i odvjetci obitelji Bubić iz Budve te Medin s područja Paštrovića. ${ }^{5}$

4 O ovom fenomenu, inače karakterističnom za ranomoderno europsko ratovodstvo, u mletačkoj vojsci s konca 17. i početka 18. stoljeća vidi: Nikola MARKULIN, Mletačka vojna organizacija u Dalmaciji i Boki od Morejskog rata (1684. - 1699.) do Požarevačkog mira 1718., Doktorska disertacija, Sveučilište u Zadru, 2015.; N. MAR Kulin, Vojno poduzetništvo u Mletačkoj Dalmaciji i Boki od 1700. do 1718. godine. Opširnu argumentaciju o tome kako se oslanjanje države na vojne poduzetnike nastavilo kroz 18. stoljeće usprkos nastojanjima državne administracije da istisne privatnu inicijativu vidi u: L. Čoralić - N. MARKULIN, Kotorski plemić Benedikt Paskvali.

5 O istaknutim dalmatinskim i bokeljskim časnicima, zapovjednicima mletačkih prekomorskih postrojbi kroz 18. stoljeće usporedi: Giuseppe SABALICH, Huomeni d'arme di Dalmazia, Zara, 1909.; G. SABAlich, La Dalmazia guerriera, Archivio storico per la Dalmazia, anno III, vol. V, fasc. 30, Roma, 1928., 279 - 300; Arduino Berlam, Le milizie dalmatiche della Serenissima, Rivista dalmatica, anno XVI, fasc. 1, Zara, 1935., 47 - 58; Š. PERIČIć, Neki Dalmatinci - generali stranih vojski, Radovi Zavoda za povijesne znanosti HAZU u Zadru, sv. 42, Zagreb - Zadar, 2000., 195 - 220; L. Čoralić - Maja Katušić, Andrija Mladinić i Mihovil Anđelo Filiberi - časnici postrojbe Croati a Cavallo (iz društvene i vojne povijesti Dalmacije u XVIII. stoljeću), Povijesni prilozi, god. 28, sv. 37, Zagreb, 2009., 247 - 282; L. Čoralić, Od zapovjednika hrvatske konjice do gorljivih autonomaša - šibenska obitelj Fenzi (XVII. stoljeće - početak XX. stoljeća), Povijesni 
U proljeće 1792. godine izbio je rat između Francuske i Austrije. Nakon podužeg kolebanja Mletačka se Republika u svibnju 1794. odlučila za prokušanu metodu - proglasila je naoružanu neutralnost nastojeći na taj način zaštiti svoje, u prvom redu talijanske granice od zaraćenih vojski. ${ }^{6} \mathrm{U}$ Italiju su $s$

prilozi, god. 30, sv. 41, Zagreb, 2011., 203. - 231; L. Čoralić, Zadarski patricij Šimun Nassi pukovnik hrvatskih konjanika u mletačkoj vojsci (početak 18. stoljeća), Povijesni zbornik godišnjak za kulturu i povijesno naslijeđe, god. IV, sv. 5, Osijek, 2012., 7 - 31; L. Čoralić, Šibenski plemić Nikola Divnić (1654. - 1734.) - pukovnik hrvatske lake konjice (Cavalleria Croati), Radovi Zavoda za povijesne znanosti HAZU u Zadru, sv. 54, Zagreb - Zadar, 2012., 125 - 145; L. Čoralić, Zadarski patricij Lujo Detriko (1672. - 1749.) - zapovjednik hrvatske konjice (Cavalleria Croati), Zbornik Odsjeka za povijesne znanosti Zavoda za povijesne i društvene znanosti HAZU, sv, 32, Zagreb, 2014., 99 - 129; L. Čoralić - M. KATUšIĆ, Dalmatinci - najviši časnici mletačkih prekomorskih postrojbi u 18. stoljeću, Dalmacija u prostoru i vremenu: što Dalmacija jest, a što nije? Zbornik radova sa Znanstvenog skupa Dalmacija u prostoru i vremenu: što Dalmacija jest, a što nije? održanog 14. - 16. lipnja 2012. na Sveučilištu u Zadru (ur. Lena Mirošević i Vera Graovac Matassi), Zadar, 2014., 59 - 67; L. Čoralić - M. KATUŠIĆ, Pukovnici, bojnici, kapetani - časnici iz kaštelanske obitelji Kumbat u službi Mletačke Republike (18. stoljeće), Radovi Zavoda za povijesne znanosti HAZU u Zadru, sv. 57, Zagreb - Zadar, 2015., 145. - 183. Zasebno o Bokeljima i Crnogorcima, zapovjednicima mletačkih prekomorskih pukovnija kroz 18. stoljeće usporedi: L. Čoralić - M. Katušić, Od afričke obale do dalmatinske prijestolnice - mletački general Marko Antun Bubić (1735. - 1802.), Zbornik Odsjeka za povijesne znanosti Zavoda za povijesne i društvene znanosti HAZU, sv. 28, Zagreb, 2010., 139 - 172; L. Čoralić - M. KATUšIĆ, Crnogorac Rade Maina - mletački general u Zadru (druga polovica XVIII. st.), Povijesni prilozi, god. 29, sv. 39, Zagreb, 2010., 125 - 152; L. Čoralić, Crmničanin Marko Đikanović - pukovnik mletačkih prekomorskih postrojbi (Fanti Oltramarini), Istorijski zapisi, god. 83, sv. 3-4, Podgorica, 2011., 63 - 86; L. Čoralıć, Mletački pukovnik Ivan Krapović iz Maina (prva polovica 18. stoljeća), Arbivski zapisi, god. 18, sv. 2, Cetinje, 2011., 81 - 106; L. Čoralıć, Mletački časnik Nikola Visković i sastav vojnoga ljudstva njegove prekomorske pukovnije početkom 18. stoljeća, Historijski zbornik, sv. 65/2, Zagreb, 2012., 365 - 385; L. Čoralić - M. Katušıć, Peraštanin Tripun Štukanović pukovnik mletačkih oltramarina (druga polovica 18. st.), Anali Zavoda za povijesne znanosti HAZU u Dubrovniku, sv. 50, Zagreb - Dubrovnik, 2012., 385 - 410; L. Čoralić - M. Katušıć, Kotorski plemići Frano Buća, Gabrijel Vraćen i Nikola Paskvali - časnici mletačkih prekojadranskih vojnih postrojbi (prva polovica XVIII. st.), Povijesni prilozi, god. 31, sv. 42, Zagreb, 2012., 249 - 273; L. Čoralić - M. Katušıć, Hrvatski vojnici u posljednjim danima Mletačke Republike - kapetan Nikola Bolica i njegovi Fanti Oltramarini,Ascendere historiam. Zbornik u ćast Milana Kruheka (ur. Marija Karbić, Hrvoje Kekez, Ana Novak i Zorislav Horvat), Zagreb, 2014., 197 - 208; L. Čoralić - M. KATUŠIĆ, Kotoranin Tripun Gregorina (1719-1791) - pukovnik hrvatskih konjanika (Croati a cavallo), Anali Zavoda za povijesne znanosti HAZU u Dubrovniku, sv. 55/2, Zagreb - Dubrovnik, 2017., 375 - 406; L. Čoralić - N. Mar KUlin, Kotorski plemić Benedikt Paskvali.

6 Opširnije o tim događajima, posebice o diplomatskoj aktivnosti, vidi kod: Gaetano Cozzi Michael Knapton - Giovanni Scarabello, Povijest Venecije, sv. II, Zagreb, 2007., 696 - 704. O politici naoružane neutralnosti Mletačke Republike devedesetih godina 18. stoljeća vidi podrobnije u: Charles Dienl, Mletačka Republika, Zagreb, 2006., 181 - 183; Giovanni Distefano, Atlante storico di Venezia, Venezia, 2007., 543 - 548; Federic C. Lane, Povijest Mletačke Republike, s engleskog prevela Tihomira Mršić; stručna redaktura i pogovor Lovorka Čoralić, Zagreb, 2007. 464 - 465; Alvise Zorzi, La Repubblica del leone: Storia di Venezia, Milano, 2008., 482 - 525; Giuseppe Gullino, Storia della Repubblica Veneta, Brescia, 2011., 294 - 299. 
mletačkih prekomorskih posjeda žurno pozvane profesionalne vojne postrojbe, a istovremeno je naređena mobilizacija dalmatinskih cernida i krajini koje su trebale služiti kao pomoćne snage. ${ }^{7} \mathrm{U}$ sastavu mletačke profesionalne vojske $\mathrm{u}$ to su se vrijeme nalazile postrojbe kojima su zapovijedali časnici iz trogirske plemićke obitelji Michieli Vitturi - pukovnik (colonnello) Vicko i njegova dva rođaka, dopukovnik (tenente colonnello) Nikola i njegov sin zastavnik (alfiere) Jerolim Franjo koji je od 1796. godine imao čin kapetana (capitano). ${ }^{8}$ Analizom njihovih vojnih karijera, kao i vojničkog sastava njihovih postrojbi u ovom razdoblju, bavi se nastavak ovog rada.

\section{VOJNA KARIJERA MLETAČKIH ČASNIKA VICKA, NIKOLE I JEROLIMA FRANJE MICHIELIJA VITTURIJA, ZAPOVJEDNIKA MLETAČKIH PREKOMORSKIH POSTROJBI}

Praćenje napredovanja u vojnoj službi Republike spomenute trojice dalmatinskih časnika pruža nam priliku da uočimo nekoliko pojava u mletačkoj vojnoj organizaciji posljednjih desetljeća 18 . stoljeća koje se odnose na njezin dio čije je ishodište bio mletački posjed u Dalmaciji i Boki. Riječ je o profesionalnim pješačkim postrojbama mletačke vojske unovačenim na istočnojadranskoj obali i njezinu zaleđu, a koje su se nazivale Oltramarini, ali i o, u ovom razdoblju s njima povezanim, teritorijalnim postrojbama mletačke vojske iz Dalmacije koje se u izvorima označavaju kao cernide, krajine, colletizie i ordinanze.

HR-DAZD, fond 1, Generalni providuri Dalmacije i Albanije (dalje: GPDA), kut. 218., 49v - 57v.

8 Prema spoznajama Mladena Andreisa, rodonačelnik obitelji bio je Ulrik I. spomenut 1112. godine, a prvi je na Brač prispio pripadnik 14. generacije roda - Petar, vjerojatno rođen oko 1410. godine. Prema tradiciji rod Mičelović (Michieli) podrijetlom je iz Bosne, a na Brač se doselio iz omiške Rogoznice (Lokva Rogoznica). Neizvornim bračkim plemstvom priznati su 1657. godine, a 1677. izjednačeni su s izvornim bračkim plemstvom. Međutim, dopis upućen bračkom knezu u kojem se spominje da je obitelj Michieli već bila potvrđena kao iskonska, odaslan od strane generalnog providura Dalmacije i Albanije Gianbattiste Grimanija još 1642. godine, pokazuje da je ovaj rod pripadao izvornom bračkom plemstvu. Spominju se u Postirama tijekom 16. stoljeća, a u 17. stoljeću bilježe se i u Pučišćima i Supetru. U trogirsko su vijeće 1659. godine agregirani brački plemići, braća doktor Jerolim (1600. - 1666.) i Vicko (r. 1610.) Michieli iz Postira, sinovi Nikole Pavlova i Jelene, vjerojatno kćeri kapetana Janka Marjanovića. Jerolim je 1650. godine oženio trogirsku plemkinju Katarinu Vitturi (1628. - 1678.), sestru posljednjeg muškog potomka trogirskog plemićkog roda te je njegov sin Nikola (1654. - 1721.) počeo početkom 18. stoljeća upotrebljavati dva prezimena (Michieli Vitturi), koje su potom preuzeli svi potomci. Vidi: Mladen ANDREIs, Trogirsko plemstvo do kraja Prve austrijske uprave u Dalmaciji (1805.), Trogir, 2006., 237 - 239. O rodu Mičelović i njegovu dolasku na Brač vidi: Dasen VRsalović, Povijest otoka Brača, Brački zbornik, sv. 6, Supetar, 1968., 214. O obitelji Michieli na Braču u 16. i 17. stoljeću: Jugoslav GospodnETIĆ, Brač i njegovo pomorstvo (I), Brački zbornik, sv. 17, Supetar, 1995., 434 - 435. 
Pukovnik Vicko Michieli Vitturi od 1791. do konca Republike zapovijedao je pješačkom pukovnijom Oltramarina. Bio je sin pukovnika Šimuna (rođenog 1706. godine), ${ }^{9}$ a u spisima mletačke vojne administracije prvi smo njegov spomen pronašli 1789. godine kada je imao čin dopukovnika. Tada se njegova (osobna) pješačka satnija nalazila u sastavu pukovnije Oltramarina pukovnika Nikole Scutarija. ${ }^{10}$ Godine 1793. Vicko je u činu pukovnika zapovijedao pješačkom pukovnijom. ${ }^{11} \mathrm{U}$ sastavu njegove pukovnije bilježi se i satnija kojom je zapovijedao Vickov stariji bratić Nikola Michieli Vitturi.

Nikola je bio sin Jerolima Michielija Vitturija, starijeg brata pukovnika Šimuna i strica pukovnika Vicka. ${ }^{12}$ On se prvi put spominje u činu kapetana Oltramarina 1786. godine. ${ }^{13} \mathrm{U}$ razdoblju od 1786. do 1791. godine Nikola je imao čin bojnika (sargente maggiore). ${ }^{14} \mathrm{Od} 1789$. do 1793 . godine satnija bojnika Nikole nalazila se u sastavu pukovnije Oltramarina pukovnika Nikole Medina. ${ }^{15}$ Godine 1794. Nikola je imao čin dopukovnika, a njegova se osobna satnija nalazila u sastavu pukovnije Oltramarina mlađeg mu bratića, pukovnika Vicka. ${ }^{16}$

9 Šimun je zajedno sa starijim bratom Jerolimom (rođenim oko 1694. godine) bio sin spomenutog Nikole koji počinje koristiti dva prezimena - Michieli Vitturi. Sina Vicka dobio je iz braka $s$ drugom suprugom Terezom Ivellio, bračkom i splitskom plemkinjom. Vidi: M. ANDREIS, Trogirsko plemstvo, 237 - 239. Opće podatke o obitelji usporedi i u: Carl Georg Friedrich HEYER von Rosenfeld, Der Adel des Königreichs Dalmatien, Nürnberg, 1873. (pretisak: Zagreb, 1995.), 61; Doimo Fortunato Karaman, Albero genealogico della famiglia Michieli Vitturi, Bulletino di archeologia e storia Dalmata, anno XII, no. 4, 5-6, 7-8, 9, 10, 11-12, Spalato, 1899. (na ovitku, nepaginirano); Andre JuTronić, Bračke teme, Split, 2002., passim.

10 IT - Archivio di Stato di Venezia (dalje: ASVe), Inquisitori sopra amministrazione dei pubblici ruoli (dalje: Inquisitori ... pubblici ruoli). Oltramarini, b. 701. Reggimento Colonnello Nicolò Scutari. Valja spomenuti kako se uz čin dopukovnika Vicka Michielija Vitturija bilježi i titula conte.

11 ASVe, Inquisitori ... pubblici ruoli. Oltramarini, b. 644. Reggimento Colonnello conte Vicenzo Michieli Vitturi.

12 Nikola je rođen 1721. godine kao sin Jerolima i contesse Lukrecije Posedarski iz Zadra. Oženio je Maddalenu Sograffi iz Verone te s njom imao sinove Franju Antuna (r. 1747.) i kapetana Jerolima Franju (rođenog 1755. godine). Vidi: M. ANDREIs, Trogirsko plemstvo, 237.

13 HR-DAZd, fond 1, GPDA, kut. 201, $287-287 \mathrm{v}$.

14 Nikola je odlukom generalnog providura Dalmacije i Albanije Francesca Faliera u srpnju 1786. godine promaknut u čin bojnika, ali se u spisima središnje državne administracije 1787. i 1788 . godine još uvijek navodi kao kapetan u sastavu pukovnije Oltramarina pukovnika Bartola Knapića. Možda su središnje državne vlasti odgodile provedbu odluke generalnog providura, pa odatle proizlazi nesuglasje u spisima središnje i provincijske administracije. Usporedi: ASVe, Inquisitori ... pubblici ruoli. Oltramarini, b. 604A. Reggimento Colonnello Bartolomeo Knapich.

15 ASVe, Inquisitori ... pubblici ruoli. Oltramarini, b. 454. Reggimento Colonnello conte Nicolò Medin.

16 ASVe, Inquisitori ... pubblici ruoli. Oltramarini, b. 643. Reggimento Tenente colonnello Vicenzo Michieli Vitturi. 
Značajno je primijetiti kako se u sastavu pješačke satnije Nikole Michielija Vitturija od 1787. do 1791. godine nalazio i njegov sin Jerolim Franjo s činom zastavnika, rođen u Trogiru 1755. godine. ${ }^{17}$ Jerolim Franjo je 1796. godine imao čin kapetana i zapovijedao je pješačkom satnijom u sastavu pukovnije Oltramarina spomenutog pukovnika Medina. ${ }^{18}$

Pozicioniranje pripadnika jedne obitelji na zapovjedničkim položajima unutar istih postrojbi (Nikola je bio dopukovnik u pukovniji svog bratića Vicka, a Jerolim Franjo zastavnik u satniji svog oca Nikole) bila je jedna od glavnih karakteristika mletačke vojne organizacije koncem 17. i početkom 18. stoljeća. Proizašla je iz potrebe države da se zbog ograničenog dosega vlastite administracije prilikom novačenja i organiziranja vojnih postrojbi oslanja na privatnu inicijativu vojnih poduzetnika, pa su odatle, kao što je to bio slučaj diljem Europe, vojne postrojbe organizirane državno-privatnim partnerstvom. No, ovaj primjer trojice časnika obitelji Michieli Vitturi, zajedno s još nekim primjerima iz naših nedavnih istraživanja, ukazuje na to da se praksa sukladno kojoj su rodbinske veze činile važnu polugu za napredovanje u vojnoj službi nastavila do konca Presvijetle Republike. Dakako, ponajprije je tomu bilo tako u slučaju društvenih elita mletačkih istočnojadranskih posjeda. Valja pritom imati na umu kako su slične prakse bile vrlo raširene i u većini ostalih europskih vojski 18. stoljeća. ${ }^{19}$

Zapravo, mletačka je središnja državna administracija, kao što je bio slučaj i u ostalim europskim vojskama 18. stoljeća, nastojala ograničiti takve prakse i vojne postrojbe staviti čvršće pod svoj nadzor. Zorno o tomu svjedoči spis o napredovanju Nikole Michielija Vitturija iz čina kapetana u čin bojnika. Naime, kako smo prije kazali, providur Francesco Falier je u srpnju 1786. godine za bojnika pukovnije Oltramarina Knapich imenovao kapetana Nikolu Michielija Vitturija. Prema pisanju providura Faliera, mjesto bojnika ove pukovnije već je nekoliko mjeseci bilo upražnjeno, zbog toga što se nakon promaknuća

17 Jerolim Franjo je oko 1788. godine oženio Anđelu Lando iz Kotora s kojom je imao sinove Nikolu (r. 1790.), Luju (Alvise, r. 1794.) i Andriju (r. i u. 1804.) te kćer Anticu (r. 1797.). M. ANDREIS, Trogirsko plemstvo, 237.

18 ASVe, Inquisitori ... pubblici ruoli. Oltramarini, b. 654. Reggimento Colonnello conte Nicolò Medin.

19 O toj pojavi u mletačkoj vojsci 17. i na početku 18. stoljeća vidi: N. MAR KULIN, Vojno poduzetništvo u Mletačkoj Dalmaciji i Boki od 1700. do 1718. godine; N. MARkulin, Vojno poduzetništvo u mletačkoj Dalmaciji i Boki za vrijeme Morejskog rata (1684. - 1699.), Radovi Zavoda za povijesne znanosti HAZU u Zadru, br. 56, 2014., 91 - 142. Za drugu polovicu 18. stoljeća vidi: L. Čoralić - N. Markulin, Kotorski plemić Benedikt Paskvali (1704. - 1790.) - zapovjednik mletačkih prekomorskih kopnenih postrojbi, Acta Histriae, 2018. (u postupku objavljivanja). U navedenim radovima nalazi se i opsežan popis literature u kojoj se takve prakse raščlanjuju na primjerima ostalih europskih ranomodernih vojski. 
dotadašnjeg bojnika Donè u dopukovnika nisu mogle održati provjere (prove) jer su postrojbe (satnije) iz ove pukovnije bile raspršene na raznim dužnostima po Dalmaciji. Odlukom Senata od 18. svibnja iste godine Nikola Michieli Vitturi promaknut je bez uobičajenih provjera jer ih je već bio prošao 1768. na Lidu i 1775. godine na Krfu, o čemu su postojala pisana svjedočanstva ( fedi) kod magistrature nadležne za vojnu administraciju - Savio alla Scrittura. ${ }^{20}$ Providurova odluka ravnala se prema zakonu o promaknućima u mletačkoj vojsci iz 1740. godine kojim su propisana pravila za ispite (esami) i provjere (prove) te metode kojima će se vrednovati potvrde i patenti (fedi, rimesse, e patenti) svakog kandidata za napredovanje. ${ }^{21}$ Upravo je taj zakon trebao profesionalizirati časnički kadar mletačke vojske. No, kao što to pokazuje primjer trojice časnika Michieli Vitturi, obiteljske su veze još uvijek, iako zacijelo ni približno onako snažno kao što je to bio slučaj u vrijeme dva posljednja Mletačko-osmanska rata, bile važan čimbenik u izgradnji uspješne vojne karijere.

$\mathrm{Na}$ koncu valja dodati kako su i tvorci zakona za napredovanje u vojnoj službi svjesno ostavili prostor kojim su društvenim elitama više časničke činove učinili dostupnijima. Naime, dok su se svi upražnjeni časnički činovi trebali popunjavati iz redova nižih časnika (i pričuvnih časnika istog čina), čin zastavnika bio je izravno otvoren mladićima plemićkog podrijetla. Takav je postupak opravdan argumentom kako je to najniži čin koji zahtijeva kvalitete i vrline koje se rijetko pronalaze među „običnim“ časnicima. Jerolim Franjo Michieli Vitturi svoju je vojnu karijeru započeo upravo kao zastavnik u očevoj satniji.

Druga zanimljiva pojava u mletačkoj vojsci potkraj 18. stoljeća kojoj valja posvetiti više pozornosti odnosi se na praksu inkorporiranja prisilno unovačenih vojnika teritorijalnih postrojbi u profesionalne postrojbe Republike. Naime, kako je već bilo kazano, Republika je uslijed Revolucionarnih ratova u svibnju 1794. proglasila naoružanu neutralnost. Pritom se okrenula metodama prokušanim u sličnim situacijama u vrijeme Rata za španjolsku baštinu i Rata za austrijsku baštinu. Venecija je u prvom redu trebala zaštititi svoje granice u Italiji, a reakcija mletačkih vojnih vlasti u tom je smislu bila promptna. Već od 19. svibnja 1794. godine generalni providur Dalmacije i Albanije Alvise Marin naredio je podizanje i ustrojavanje teritorijalnih vojnih postrojbi koje su u Dalmaciji i Boki (u pravilu kao posade obalnih gradova i važnijih utvrda) trebale zamijeniti profesionalne postrojbe žurno poslane $u$ Italiju. ${ }^{22} \mathrm{U}$ jednoj od

$20 \quad$ HR-DAZD, f. 1, GPDA, kut. 201., $287-287 \mathrm{v}$.

21 HR-DAZD, f. 366, Fond obitelji Zanchi, kut. 6., bez paginacije.

22 HR-DAZD, fond 1, GPDA, kut. 218., 49v - 57v. 
dvadesetak takvih naredbi providur je i eksplicitno naveo kako je dukalom od 10. svibnja Senat iz Dalmacije u Italiju od profesionalnih vojnih postrojbi pozvao osam satnija prekomorskog pješaštva (fanti nazionali), četiri konjaničke satnije Cavalleria Croata te čak deset pješačkih talijanskih satnija (fanti Italiani), pa je naložio ustrojavanje teritorijalnih postrojbi koje bi ih trebale zamijeniti. ${ }^{23}$

Iz popisa pješačkih postrojbi (satnija) Oltramarina kojima su zapovijedali Vicko, Nikola i Jerolim Franjo Michieli Vitturi koje su od 1793. do 1796. godine na mletačkim talijanskim posjedima izradili službenici mletačke vojne administracije vidljivo je kako su u tom periodu značajan udio ljudstva činili vojnici teritorijalnih postrojbi (cernida) unovačeni u Istri i Dalmaciji uslijed potrebe Republike da poveća svoju vojsku i zaštiti svoje granice od europskih vojski sukobljenih $\mathrm{u}$ Revolucionarnim ratovima. ${ }^{24}$ Valja naglasiti kako uvrštavanje vojnika teritorijalne milicije u profesionalne vojne postrojbe u ovom slučaju nije bila ad hoc mjera nekog visokog vojnog zapovjednika na terenu, već od strane središnje državne vlasti unaprijed planirana i provedena odluka. Naime, generalni je providur 26. svibnja 1794. godine u Dalmaciji izdao naredbu koju je prethodno (14. svibnja) dobio od Senata, a prema kojoj je trebalo unovačiti 1375 vojno sposobnih muškaraca i od njih ustrojiti postrojbe na teritorijalnom principu. Odmah je valjalo probrati 375 najsposobnijih i poslati ih na Lido, a ostalih 1000 držati spremnima za slanje u Italiju gdje su trebali biti uvrštavani u tamošnje pješačke satnije Oltramarina. ${ }^{25}$ Tamo su trebali služiti dvije godine i za to vrijeme primati redovnu plaću i vojnu odoru vojnika Oltramarina. U spisu je dalje propisano kako će dobiti naknadu (donativo) od dva dukata u trenutku prve smotre u Italiji kojom su trebali podmiriti troškove puta do Italije, a sličnu su naknadu trebali dobiti i po završetku službe. Država je odredila da će dobiti naknadu u iznosu trodnevne vojničke plaće za vrijeme

23 Chiamate ai Lidi della Serenissima Dominante con Sovrana Ducali 10. corrente per rinforzo ai Presidij d'Italia otto Compagnie Nazionali complete dalla rimanenti al numero di teste 48, otto Compagnie di Cavalleria Crovata e dieci de fanti Italiani... HR-DAZD, fond 1, GPDA, kut. 218., 54v - 55. Zanimljivo je primijetiti kako providur terminom Craine ne označava teritorijalnu vojsku na posjedima „Stare stečevine“ ...il Lievo di quel numero di Craine, e Scogliani... iako je jasno da se radi o postrojbama i vojnicima organiziranim na istom principu što potvrđuje naša nešto starija razmišljanja o nomenklaturi mletačkih postrojbi u Dalmaciji. Usporedi: N. MARKULIN, Mletačka organizacija teritorijalnih vojnih postrojbi, $251-287$.

24 Detaljnu raščlambu ljudstva postrojbi spomenutih časnika iz obitelji Michieli Vitturi u razdoblju od 1793. do 1796. godine vidi u daljnjem izlaganju.

25 ...la trascielta di 375 di esse per innoltrarle prontamente ai Lidi della Serenissima Dominante, dovendo trattenere l'altre 1.000 pronte a Pubblica disposizione riservate ugualmente a passar in Italia per esser descritte nelle Compagnie di quel Ripparto ed ivi servire per il corso al piu di due anni... HR-DAZD, fond 1, GPDA, kut. 218., $54-54 \mathrm{v}$. 
od trenutka unovačivanja do dolaska u luku iz koje su trebali biti poslani za Veneciju, a desetodnevna plaća trebala im je biti isplaćena u trenutku dolaska $u$ luku, čime bi mogli podmiriti svoje uzdržavanje (suffraggio e sostentamento) do polaska. O svemu je tome valjalo voditi precizne bilješke i slati ih institucijama središnje vojne administracije (Savio di Terra Ferma alla Scrittura). No, treba primijetiti kako novac nije trebao biti isplaćivan na ruke vojnicima, već jednom njihovom upravitelju (direttore) kojeg je odredila država što je, dakako, otvaralo mogućnost pronevjerama i prijevarama, a treba znati kako je manipulacija vojničkim plaćama bila jedan od uobičajenih načina ostvarivanja dodatne zarade njihovih časnika u ranomodernim vojskama. ${ }^{26} \mathrm{Za}$ upravitelja ovih teritorijalnih postrojbi providur je postavio bojnika Steffana Leonnija koji je, osim isplate novca vojnicima, trebao voditi računa o sprječavanju dezerterstva i njihovoj vojnoj obuci. Providur je pritom istaknuo kako je Leonni istu funkciju bio obnašao i za vrijeme njegovih prethodnika Francesca Faliera i Alvise Marina. ${ }^{27}$ Potonji navod jasno ukazuje kako je praksa popunjavanja profesionalnih postrojbi vojnicima cernida i krajini postojala i prije, čime se objašnjava činjenica kako je u popisu satnije pukovnika Vicka Michielija Vitturija već u studenom 1793. godine zabilježen znatan udio vojnika cernida. ${ }^{28}$

Poznato je kako su talijanske $\mathrm{i}$ istarske cernide bile angažirane na istočnojadranskom bojištu u vrijeme Kandijskog i Morejskog rata. ${ }^{29}$ Prvi poznati slučaj angažmana dalmatinskih teritorijalnih postrojbi u Italiji zabilježen je u vrijeme Rata za španjolsku baštinu kada je Republika također proglasila naoružanu neutralnost. Okolnosti su, dakle, bile vrlo slične onima iz devedesetih godina 18. stoljeća, a tom je prilikom pukovnik cernida zadarskih otoka i varoši Jerolim Soppe Papali sastavio poduži elaborat u kojem je eksplicitno naveo kako su tada prvi puta vojnici teritorijalnih postrojbi iz Dalmacije inkorporirani u sastav postrojbi profesionalne vojske. ${ }^{30}$ To su i tada bile pješačke postrojbe

26 O tomu vidi: David PARrott, The Business of War. Military Enterprise and Military Revolution in Early Modern Europe, Cambridge: Cambridge University Press, 2012. Za mletačku vojsku u 17. i 18. stoljeću vidi: N. MARKULIN, Vojno poduzetništvo u Mletačkoj Dalmaciji i Boki od 1700. do 1718. godine; N. MARkulin, Vojno poduzetništvo u mletačkoj Dalmaciji i Boki za vrijeme Morejskog rata.

27 HR-DAZD, fond 1, GPDA, kut. 218., 54v.

28 Detaljan popis nalazi se u nastavku teksta.

29 O angažmanu talijanskih cernida u Dalmaciji za vrijeme Kandijskog rata vidi opširnije: Domagoj Madunić, Defensiones Dalmatiae: Governance and Logistics of the Venetian Defensive System in Dalmatia During the War Of Crete (1645 - 1669), doktorska disertacija, Budimpešta: Central European University, 2012., 154 - 166; a za vrijeme Morejskog rata: N. MAR KULIN, Mletačka vojna organizacija, $30-33$.

30 ...il vedersi incorporati nelle Truppe Regolate, cosa novissima... HR-DAZD, f. 359, kut. 6., 140 - $142 \mathrm{v}$. 
Oltramarina novačene na istočnojadranskoj obali i u njezinu zaleđu u kojima je zapovjedni jezik bio hrvatski kojim su govorili i vojnici cernida i krajini. Tom je prigodom Soppe Papali bio upozorio na niz problema proizašao iz takvih praksi. Ponajprije se to odnosilo na izrabljivanje vojnika cernida od strane profesionalnih časnika i vojnika, njihov strah da će s profesionalnim postrojbama biti poslani na Levant odakle se nikada neće vratiti kućama te, po njegovu sudu predugo predviđeno razdoblje boravka u Italiji od tri godine, što je rezultiralo njihovim učestalim dezertiranjem. ${ }^{31}$

Ovi, dakle, postupci objašnjavaju činjenicu da se u popisima postrojbi Oltramarina kojima su devedesetih godina 18. stoljeća zapovijedali časnici iz obitelji Michieli Vitturi nalazi veliki broj vojnika cernida uslijed čega su te satnije u svom sastavu imale neuobičajeno veliki broj vojnika i časnika (uobičajena se snaga pješačke satnije Oltramarina u 18. stoljeću kretala od 50 do 80 ljudi). Ujedno, ovi postupci govore u prilog našim ranijim tezama o tome kako su postrojbe mletačke vojske ustrojene na teritorijalnom principu u pogledu borbene djelotvornosti i vojne discipline bile inferiorne profesionalnim postrojbama (posve suprotno stajalište ima starija generacija domaćih povjesničara). ${ }^{32}$ Ovdje samo uzgred valja pripomenuti kako ni u kojem slučaju mletačke teritorijalne postrojbe $s$ konca 18. stoljeća ne bi trebalo poistovjetiti sa suvremenom francuskom revolucionarnom vojskom koja se od 1793. godine popunjava općom mobilizacijom (levée en masse). Naime, dok su prve ustrojavane od (u pravilu) prisilno unovačenih podanika, vojska revolucije popunjavana je na temelju opće vojne obaveze svojih građana kojima je zauzvrat jamčila građanska i (u slučaju jakobinske vlade) politička prava što je, dakako, proizlazilo iz nastajanja novog tipa političke zajednice - nacionalne države. ${ }^{33}$

\section{ANALIZA SASTAVA POSTROJBI KOJIMA SU ZAPOVIJEDALI VICKO, NIKOLA I JEROLIM FRANJO MICHIELI VITTURI}

Prvi konkretniji podatci koje bilježimo o Vicku Michieliju Vitturiju, a vezani su uz njegovu vojnu službu, odnose se na djelovanje u činu kapetana

31 N. MARKULIN, Mletačka organizacija teritorijalnih vojnih postrojbi, 277 - 279.

32 Opširno o ovoj problematici vidi u: N. MARKULIN, Mletačka vojna organizacija u Dalmaciji i Boki; te N. MARKULIN, Mletačka organizacija teritorijalnih vojnih postrojbi u Dalmaciji.

33 Opširnije vidi u: Everett Carl Dolman, The Warrior State. How military Organization Structures Politics, New York, 2004.; Thomas Hip pler, Citizens, Soldiers and National Armies. Military service in France and Germany, 1789-1830, London - New York, 2008. 
satnije u pukovniji Marka Ginnija, ${ }^{34}$ a promatrano razdoblje zahvaća raspon od 1774. do 1779 . godine. ${ }^{35}$ Ta je postrojba brojila 99 časnika, dočasnika i običnih vojnika, a potrebno je napomenuti da je vjerojatno kroz navedeno razdoblje velik dio njih bio prekrižen (oznaka kojom se naznačavalo da je vojnik prestao sa vojnom službom, prešao u drugu postrojbu ili dezertirao), a na njihova su mjesta pristizali novi vojnici. Stoga ovaj popis faktički sadrži sveukupno vojno ljudstvo koje je od 1774. do 1779. godine (ali ne istovremeno) djelovalo u satniji kapetana Vicka Michielija Vitturija. Kada je riječ o časničkom i dočasničkom kadru, uz kapetana Vicka bilježe se dokapetan (tenente capitano) Marko Antun Scutari, zastavnici Nikola Knapić i Petar Vidali, brojni narednici (sargente) Petar Atlagić, Frane Bilas, Pietro Bittuari, Nikola Bosnić, Jure Čipćić, Dimo Janšić, Blaž Lupšić, Andrija Sliperić i Frane Zadrić te kao bubnjari (tamburo) Ivan Krstitelj Bravazzo, Antun Garetić, Antun Šimera, Anđelo Valentinić, Tadija Visinine i Ivan Zadrić. Kada je riječ o zavičajnom podrijetlu pripadnika ove postrojbe (vidi Grafikon 1), ono često nije navedeno (63,64 \%), ali na osnovu prezimena rečenih vojnika možemo pretpostaviti da potječu iz Dalmacije ili Boke kotorske. Izrijekom se na Dalmatince odnosi 22,22 \% od ukupnog broja vojnika. Od tada većih gradova bilježe se Split, Šibenik i Trogir, ali i niz područja, odnosno manjih mjesta uzduž obale i zaleđa (otok Brač,

34 Marko Ginni odvjetak je istaknute vojničke obitelji zavičajem iz Albanije koja je stoljećima davala zapažene časnike u mletačkim prekomorskim jedinicama. O obitelji usporedi podrobnije: L. Čoralıć, Albanska obitelj Ginni u povijesti Dalmacije i Istre (XVI. i XVII. st.) - prilog poznavanju komunikacija duž istočnojadranske obale, Povijesni prilozi god. 26, sv. 33, Zagreb, 2007., 271 287. Kroz široko vremensko razdoblje od sredine 18. stoljeća do konca sedamdesetih godina istoga stoljeća satnijama u Ginnijevoj pukovniji zapovijedali su sljedeći časnici (navodimo ih prema mjestima i godinama popisivanja): bojnici (Sargente maggiore) Atanasio Bua (Brescia, 1748.; Salo, 1749.) i Anastasio Paramigotti (Brescia, 1748.; Brescia, 1749.), kapetani Gicca Ellia Builli (Verona, 1749.), Gicca Andrea Ginni (Verona, 1748. i 1749.; Brescia, 1749.), Antonio Theotochi (Brescia, 1748.; Verona 1749.), Gerolimo Theotochi (Verona, 1749.), Elia Cristoforo Bua (Brescia, 1749.), Gicca Ellia Becilli (Verona, 1749.), Pietro Becilli (Verona, 1747.), Pietro Mezzera (Verona, 1747.), dokapetani (Capitan tenente) Dimo Andrea Ginni (Verona, 1749.) i Gicca Cocca (Verona, 1747.; Brescia, 1748.). Iako podatci sežu još u kasne četrdesete godine 18. stoljeća, nismo u mogućnosti s potpunom sigurnošću utvrditi je li Ginni navedenom pukovnijom zapovijedao cijelo vrijeme. Uz to, opaža se da je riječ o postrojbama Grka, dočim su od sedamdesetih godina 18. stoljeća časnici (zapovjednici satnija) i njihovo vojno ljudstvo ponajprije s istočnojadranskog područja. Nadalje, u razdoblju od 1774. do 1779. godine (satnijama) pukovnika Ginnija zapovijedali su (mjesta popisivanja satnija nisu jasno navedena u izvoru): bojnik Spiridon Antun Longo, kapetani Petar Bellafusa, Anđelo Svilanović, Antun Dandria, Franjo Grisogono, Danijel Tivić (Tiurić), Grgur Knapić, Petar Scutari i Gerolamo Vidali.

35 ASVe, Inquisitori ... pubblici ruoli. Oltramarini, b. 604A. Reggimento Colonnello Marco Ginni. Compagnia Capitan Vincenzo Michieli Vitturi. Točna mjesta popisivanja u izvoru nisu izrijekom navedena. 


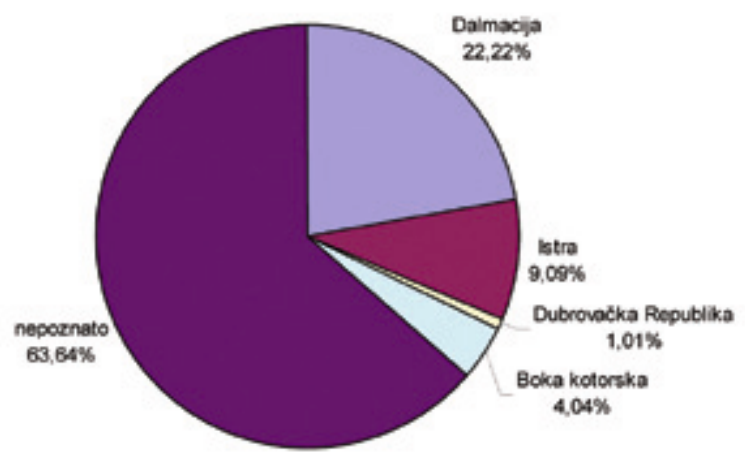

Grafikon 1. Zavičajno podrijetlo vojnog ljudstva u satniji kapetana Vicka Michielija Vitturija u razdoblju od 1774 . do 1779 . godine

Drniš, Kaštela, Klis, Neretva, Ogorje, Sinj i druga). Iz Istre je potjecalo 9,09 \% vojnika; iz Boke Kotorske (Kotor i Herceg Novi) njih 4,04 \% te naposljetku s područja Dubrovačke Republike (grad Dubrovnik) samo 1,01 \%. ${ }^{36}$

Sljedeći spomen Vicka Michielija Vitturija u navedenom mletačkom izvoru bilježimo u razdoblju od 1789. do 1792. godine, kada je imao čin potpukovnika. ${ }^{37}$ Njegova se satnija Oltramarina nalazila u sastavu pukovnije Nikole Scutarija, ${ }^{38}$ a popisana je u Zadru (1789.) i Mletcima (1791. i 1792. godine). Za ovu nam je prigodu zanimljiv popis nastao u Zadru 31. kolovoza 1789. godine. Tada je Vickova satnija brojala 46 časnika, dočasnika i običnih vojnika, što je - u odnosu na prethodni popis i gotovo sto zabilježenih vojnika - uobičajen broj kada je riječ o pješačkim postrojbama toga vremena. Dočasnički su dio ljudstva činili zastavnik Antun Fabijan Scutari, dva narednika (Mate Fališić i Lovro Matošević), tri kaplara (caporale) (Lovre Bilanović, Ivan Bratulić i Mate Trustić), dva kadeta (cadetto) )Carlo Giuseppe Bontempo i Giacomo Antonio Dibri), dočim se kao

36 Cjelovit popis časnika, dočasnika i vojnika iz satnije kapetana Vicka Michielija Vitturija načinjen od 1774. do 1779. godine vidi u Prilogu broj 1 na kraju rada.

37 Uz čin potpukovnika Vicka Michielija Vitturija bilježi se i titula conte.

38 U sastavu pukovnije Nikole Scutarija djelovale su satnije kojima su, uz Vicka Michielija Vitturija, zapovijedali sljedeći časnici: bojnik Giovanni Paravia (Kotor, 1789.), kapetani Marko Antun Scutari (Kotor, 1793.), Anđelo Marija Antivari (Zadar, 1789. i 1792.), Marko Antivari (Kotor, 1789.), Franjo Antivari (Kotor, 1789.), Alvise Rosani (Mletci, 1790. i 1792.), Andrija Franjo Grančić (Kotor, 1789. i 1792.) i Juraj Vučetić (Kotor, 1789.). Jednu je satniju osobno predvodio pukovnik Scutari (compagnia propria), a popisana je u Zadru (1791., 1792. i 1793.) i u Šibeniku (1791.). Usporedi: ASVe, Inquisitori ... pubblici ruoli. Oltramarini, b. 701. Reggimento Colonnello Nicolò Scutari. 


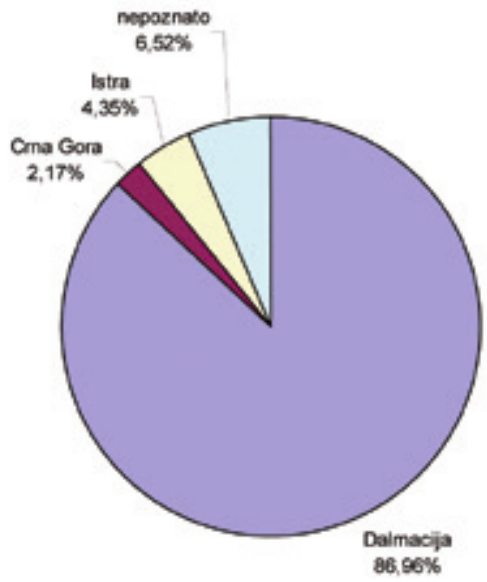

Grafikon 2. Zavičajno podrijetlo vojnog ljudstva u satniji kapetana Vicka Michielija Vitturija prema popisu načinjenom u Zadru 31. kolovoza 1789. godine

glazbena pratnja bilježe bubnjar Luka Kišević i pifarist (piffaro) Nikola Bratulić. ${ }^{39}$ Razmatrajući zavičajno podrijetlo ovdje prisutnog vojnog ljudstva (vidi Grafikon 2), opažamo da velika većina ( $86,96 \%$ ) potječe iz Dalmacije, pri čemu se uz veće gradove (Split, Šibenik, Trogir, Zadar) i gradiće (Obrovac, Pag, Skradin, Vis) ponovno bilježi i cijeli niz manjih naselja (Bibinje, Dugopolje, Islam, Kaštela, Kula Atlagića, Murter, Radovin, Rogoznica, Sukošan i druga). Nepoznatog, odnosno neoznačenog podrijetla bilo je $6,52 \%$ vojnika, a prema prezimenima možemo pretpostaviti da su dolazili s istočnojadranske obale ili (u primjeru dvojice kadeta) s Apeninskog poluotoka, najvjerojatnije s područja Veneta. Naposljetku, u malenom se broju primjera bilježe i Istrani (izrijekom je u jednom primjeru kao mjesto podrijetla navedena Pula) - zastupljeni u ukupnome omjeru s $4,35 \%$ te Crnogorci $(2,17 \%) .{ }^{40}$

U pratećem razdoblju od 1791. do 1794. godine Vicko Michieli Vitturi, iako još uvijek bilježen u činu potpukovnika - već je zapovijedao jednom od pješačkih pukovnija. ${ }^{41} \mathrm{U}$ sastavu te pukovnije djelovale su, uz njegovu osobnu, satnije kojima su zapovijedali sljedeći časnici, mahom u činu kapetana: Juraj Rado

39 Satniji je naknadno pridodano 12 novih vojnika za koje su popisivači navodili i njihovu dob (od 18 do 25 godina) i neke fizičke značajke (uglavnom smeđokosi i srednjeg rasta).

40 Cjelovit popis časnika, dočasnika i vojnika iz satnije potpukovnika Vicka Michielija Vitturija načinjen 31. kolovoza 1789. godine u Zadru vidi u Prilogu broj 2 na kraju rada.

41 ASVe, Inquisitori ... pubblici ruoli. Oltramarini, b. 643. Reggimento Tenente colonnello conte Vicenzo Michieli Vitturi. 
(Vicenza, 1792.), Anđelo Marija Antivari (Kotor, 1794.), Marko Antivari (Kotor, 1794.), Franjo Antivari (Kotor, 1794.), Juraj Vučetić (Kumbor, 1793.), Andrija Franjo Grančić (Istra, 1793.), Alvise Rosani (Zadar, 1793.) i Vickov stariji bratić Nikola. ${ }^{42} \mathrm{U}$ istome razdoblju bilježimo i nekoliko popisa koji se odnose na osobnu postrojbu potpukovnika Vicka Michielija Vitturija. Načinjeni su na Lidu (1. ožujka 1791. i 1. ožujka 1792.), a za razmatranje uzeti ćemo popis nastao na Lidu 1. ožujka 1792. godine. Osobna je satnija potpukovnika tada brojila ukupno 82 časnika, ${ }^{43}$ dočasnika, članova glazbene pratnje i običnih vojnika. U ovome popisu zavičajna mjesta vojnog ljudstva nisu navedena, a razlog tomu vjerojatno je i činjenica da se - u većini primjera - ponavljaju vojnici iz prethodnog popisa. Stoga, uz vjerojatno manja odstupanja koja bez izrijekom navedenih podataka o zavičaju vojnika (i o njihovim osobnim značajkama), možemo smatrati da je struktura podrijetla nalik onoj koja je zabilježena 1789. godine u Zadru.

Godine 1793. Vicko Michieli Vitturi bilježi se kao pukovnik prekomorskih pješačkih postrojbi. ${ }^{44} \mathrm{U}$ sastavu njegove pukovnije nalazile su se satnije kojima su zapovijedali sljedeći časnici: bojnici Franjo Antivari (Mletci, 1794.) i Giovanni Paravia (Kotor, 1793.), kapetani Andrija Franjo Grančić (Mletci, 1795.), Juraj Vučetić (Kotor, 1794.) i Marko Antivari (Kotor i Mletci, 1794.), a zanimljivo je napomenuti da u pukovniju bio uključen i njegov stariji bratić Nikola (Mletci, 1794.). Nadalje, raspolažemo is nekoliko popisa osobne satnije pukovnika Vicka Michielija Vitturija. Popisi su redovito bili načinjeni u Mletcima, a datumi su 29. rujna 1793., 29. rujna 1794 ., 31. prosinca 1794 ., 30. srpnja 1795 . te 29 . rujna 1795. godine. Za ovo smo istraživanje izdvojili popis iz 1793. godine. Satnija je u svome osnovnom sastavu tada brojila 69 vojnika, zavičajem iz raznih dijelova Istre i Dalmacije (Zadar, Šibenik, Trogir, Split i njihova okolica). Mnogi od njih bili su zabilježeni i u prethodno analiziranim popisima. Međutim, satnija je tada popunjena novim ljudstvom, točnije pridodano joj je još 46 vojnika, mahom pripadnika teritorijalnih snaga (cernide). ${ }^{45} \mathrm{Za}$ osmoricu novopridošlih vojnika zavičajno podrijetlo nije navedeno, ali s velikom vjerojatnošću možemo

42 Popisi nisu sadržani u zasebnim bilježnicama, već na odvojenim listovima (fogli sciolti).

43 Uz Vicka Michielija Vitturija kao časnici bilježe se i zastavnik Antun Fabijan Scutari, narednik Lovro Matošević, kaplari Lovre Bilinović, Mate Trustić, Ivan Balinović (u prethodnom popisu naveden prezimenom Bratulić), kadet Carlo Giuseppe Bontempo, bubnjar Luka Kišević i pifarist Nikola Bratulić. Dakle, uz manja odstupanja, posebice u pisanju nekih prezimena, časnički i dočasnički kadar ostao je isti. Slično je i s običnim vojnicima koji se velikim dijelom ponovno bilježe, uz - kako napominjemo - uz određena manja odstupanja u pisanju prezimena.

44 ASVe, Inquisitori ... pubblici ruoli. Oltramarini, b. 644. Reggimento Colonnello conte Vicenzo Michieli Vitturi.

45 Razlozi njihova uključivanja u satniju protumačeni su na početku ovog rada. 


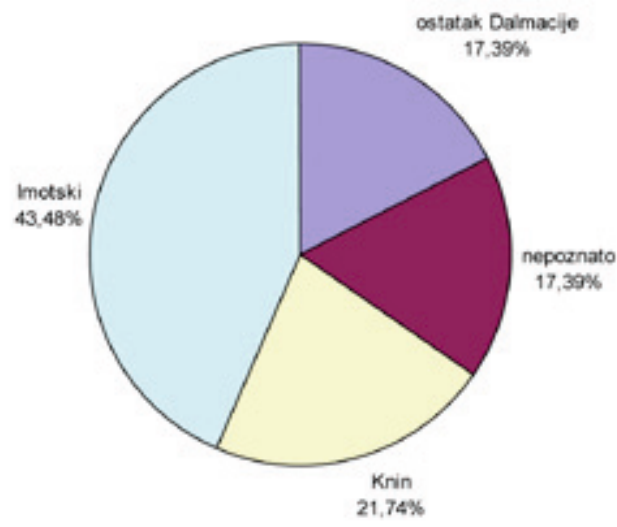

GrafiKon 3. Zavičajno podrijetlo novopridošlog vojnog ljudstva (cernida) u satniji pukovnika Vicka Michielija Vitturija prema popisu načinjenom u Mletcima 29. rujna 1793. godine

pretpostaviti da je riječ o Dalmaciji (vidi Grafikon 3). Desetorica su s kninskog područja (territorio di Knin), a još osmorica iz pobliže označenih dijelova Dalmacije (Šibenik, Trogir, Zadar). Čak 20 naknadno dopisanih vojnika iskazalo je kao mjesto podrijetla sela Imotske krajine. Postotno su, gledajući popis dopisanih vojnika, oni s imotskog područja zastupljeni s 43,48 \% naspram 21,74 $\%$ kninskih vojnika, dočim na druge vojnike koji su iz Dalmacije ili označeni bez užeg zavičaja otpada ukupno $34,78 \%$. Konkretno, s područja Imotske krajine zastupljeni su vojnici iz sela Grabovac, Studenci i Svib, a svi su oni popisani jedan iza drugoga. Njihov postotni omjer izgleda ovako: iz Studenaca je zastupljeno 45,00 \% vojnika, iz Grabovca njih 35,00 \%, dočim je iz Sviba je dolazilo 20,00 \% pripadnika dopunske jedinice pukovnika Vicka Michielija Vitturija. ${ }^{46}$

Razmotrit ćemo podrobnije još nekoliko popisa vojnika iz osobne satnije pukovnika Vicka Michielija Vitturija. Prvi od njih načinjen je u Mletcima 29. rujna 1795 . godine. ${ }^{47}$ Osobna satnija pukovnika Vicka Michielija Vitturija brojila je u osnovnom sastavu 66 časnika, dočasnika i običnih vojnika. Uz samoga rujna 1793. godine (vidi Prilog broj 3 na kraju rada).

47 ASVe, Inquisitori ... pubblici ruoli. Oltramarini, b. 645. Reggimento Colonnello conte Vicenzo Michieli Vitturi. Uz osobnu satniju pukovnika Vicka, pojedinim su satnijama zapovijedali još i bojnik Franjo Antivari te kapetani Alvise Rosani (Mletci, 1795.), Juraj Vučetić (Zadar i Mletci, 1795.), Andrija Franjo Grančić (Mletci, 1795.), Ivan Andrija Grančić (Mletci, 1795.), Jakov Grančić (Mletci, 1795.) i Marko Antivari (Mletci, 1795.). 


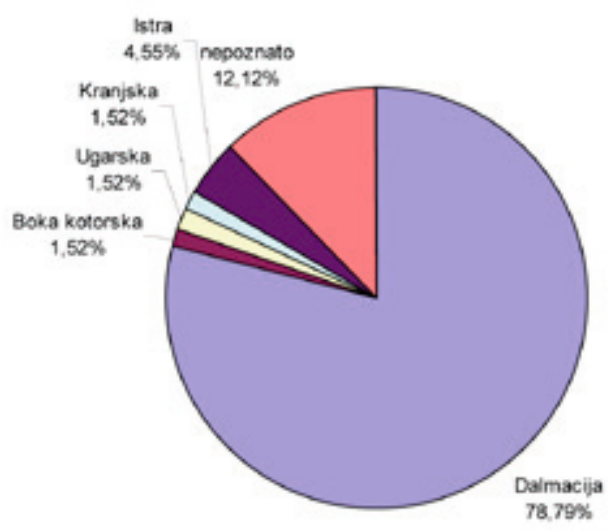

Grafikon 4. Zavičajno podrijetlo vojnog ljudstva u satniji pukovnika Vicka Michielija Vitturija prema popisu načinjenom u Mletcima 29. rujna 1795. godine

pukovnika, u satniji su kao dočasnici djelovali zastavnik Antun Fabijan Scutari, narednici Nikola Stipanović i Lovro Matošević iz Zadra, kaplari Ivo Radaban iz Kaštel Lukšića, Mihovil Perović, Filip Duić te Jure Visalović iz Skradina. Kao kadet zabilježen je Carlo Giuseppe Bontempo, a glazbenu su pratnju činili bubnjar Šime Basan iz Zadra i pifarist Marko Jakina iz Šibenika. ${ }^{48}$ Velik broj dočasnika i vojnika podudara se s prethodnim popisom. $S$ obzirom na zavičajno podrijetlo (vidi Grafikon 4), najviše je Dalmatinaca (78,79\%), pri čemu prednjače vojnici iz Kaštela (najčešće bez specifikacije o kojima je Kaštelima riječ) te s područja Imotske krajine (sela Grabovac, Studenci i Svib). U potonjim je primjerima riječ o cernidama koji u ovom popisu nisu zasebno navedeni, već su integralni dio satnije. Zapaženo je i prisustvo vojnika, vjerojatno također cernida s territorio di Knin (bez specifikacije pojedinih naselja), kao i onih iz Makarske, Šibenika, Trogira i Zadra. U pojedinačnim se primjerima bilježe i vojnici iz Rogoznice, Sinja, Splita, s otoka Šolte te iz Kule Atlagića i mjesta Kukljica na otoku Ugljanu. Ostale su zavičajne skupine zastupljene vrlo rijetko: Istra s 4,55\% (Pula i opća oznaka Istria) te Boka (Kotor), Ugarska (Ongaro) i Kranjska sa samo po 1,52\%. Naposljetku, s 12,12\% u satniji su zabilježeni vojnici čije pobliže podrijetlo ne možemo utvrditi, ali se - $s$ obzirom na njihova prezimena - može s velikom vjerojatnošću pretpostaviti da su s područja istočnojadranske obale. 
Raspolažemo s još jednim popisom Vitturijeve osobne satnije iz 1795. godine, a načinjen je na Silvestrovo u Mletcima. Ukupan broj vojnika u osnovnom sastavu iznosio je 79. Činili su ga poglavito dočasnici i vojnici zabilježeni u prethodnom popisu te je stoga i njihova zavičajna struktura uglavnom nepromijenjena (prevaga vojnika iz Dalmacije). Ono što je posebno zanimljivo velik je broj naknadno dopisanih vojnika (128), mahom cernida koji su potjecali poglavito iz Istre $(46,09$ $\%)$, pri čemu se - uz često primjenjivanu opću oznaku de Istria - kao mjesta podrijetla njih tridesetak navodi teritorij Krasa (Carso), brdovitog područja u Buzeštini. Na vojnike iz Dalmacije otpadalo je 40,63 \% cernida, ${ }^{49}$ dočim su oni nepoznatog podrijetla (najvjerojatnije je riječ o Dalmaciji) zastupljeni s 13,28 \%.

Završno razdoblje koje ćemo obraditi u svezi djelovanja pukovnika Vicka Michielija Vitturija odnosi se na 1796. i 1797. godinu, ${ }^{50}$ a uz osobnu pukovnikovu satniju postrojbama su zapovijedali bojnik Franjo Antivari (Mletci, 1796. i 1797.) te kapetani Juraj Vučetić (Mletci, 1796.), Andrija Franjo Grančić (Mletci, 1796.), Jakov Grančić (Mletci, 1796. i 1797.), Antun Scutari (Mletci, 1796.), Franjo Antivari (Mletci, 1796.), Anđelo Marija Antivari (Bergamo, 1796. i Mletci, 1797.) te Marko Antivari (Mletci, 1797.). Osobna satnija pukovnika Vicka Michielija Vitturija popisana je na Silvestrovo 1796. godine u Mletcima, a brojila je 120 časnika, dočasnika i običnih vojnika. Uz samoga pukovnika, prisutni su bili zastavnik Lovro Matošević, narednici Vicko Ković i Ivo Rabadan, kaplari Mate Balić, Filip Divić, Bajo Reić i Antun Vojnić, kadet Ivan Krstitelj Antun Arnerić te bubnjar Šime Basan. ${ }^{51}$ Zavičajna struktura ukupnog vojnog ljudstva pokazuje da su prednjačili Istrani (46,67 \%), a veliki broj njih (uz vojnike označene samo kao de Istria) potjecao je s područja buzetskog Krasa te njih možemo smatrati cernidama. Dalmatinski su vojnici bili zastupljeni s 41,67 \%, a uz one koji su kao mjesto podrijetla naveli veće gradove (Split, Šibenik, Zadar), opaža se i velik broj pripadnika postrojbe iz manjih mjesta (Imotski, Kaštela, Klis, Makarska, Šolta), odnosno s ruralnog područja (Banjevci, Gornja Jagodnja, Grabovac, Pristeg, Studenci i druga). U pojedinačnim su primjerima popisivači bilježili i vojnike iz Boke (Kotor) te s područja Kranjske (po 0,83\%), dočim za 10,00 \% mjesto podrijetla nije u izvoru izrijekom navedeno (vidi Grafikon 5). ${ }^{52}$

49 Većina cernida iz Dalmacije potjecala je iz sela Banjevci, s kninskog teritorija, iz Imotske krajine te sa zadarskog contada.

50 ASVe, Inquisitori ... pubblici ruoli. Oltramarini, b. 646. Reggimento Colonnello conte Vicenzo Michieli Vitturi.

51 Satniji je naknadno, uz tri obična vojnika, priključen pifarist Antun Armano.

52 U prilogu se objavljuje cjelovit popis vojnog ljudstva iz satnije pukovnika Vicka Michielija Vitturija načinjen 31. prosinca 1796. u Mletcima (vidi Prilog broj 4 na kraju rada). 


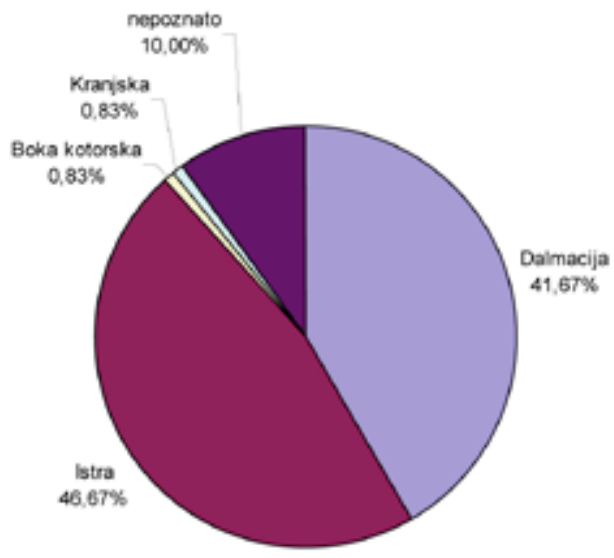

Grafikon 5. Zavičajno podrijetlo vojnog ljudstva u satniji pukovnika Vicka Michielija Vitturija prema popisu načinjenom u Mletcima 31. prosinca 1796. godine

Popis sa samoga kraja 1796. godine posljednji je, prema dosadašnjim saznanjima, podatak o vojnoj karijeri pukovnika Vicka Michielija Vitturija. Godina njegove smrti nije nam poznata, a nije navedena - iz razloga što prethodno citirana knjiga Mladena Andreisa zahvaća razdoblje do početka 19. stoljeća. Stoga ostaje mogućnost da je Vicko preminuo u Trogiru nakon te godine ili je - ako nije zabilježen u matičnoj knjizi umrlih - njegov ostatak života bio vezan za Mletke ili Veneto, slučaj koji nije rijedak za posljednje godine života niza hrvatskih časnika u mletačkoj vojnoj službi. Činjenica je da se završni popis Vickove osobne satnije i same pukovnije poklapa s završnim godinama opstojanja Serenissime te je moguće da je umirovljen, a zasigurno su njegove postrojbe raspuštene i vraćene u domovinu. U svakom slučaju, njegov životopis iziskuje i dodatna istraživanja koja će, vjerujemo, rasvijetliti još neke za sada nepoznate pojedinosti.

Prvi spomen Nikole Michielija Vitturija bilježimo u lipnju srpnju 1786. godine. Tada je naime Francesco Falier, mletački generalni providur Dalmacije i Albanije, za bojnika pukovnije Oltramarina kojom je zapovijedao Bartol Knapić imenovao kapetana Nikolu Michielija Vitturija.

Međutim, sumnju da je ta odluka bila smjesta i provedena pružaju podatci iz 1787. i 1788. godine kada je još uvijek u činu kapetana zapovijedao satnijom 
u sastavu pukovnije Bartola Knapića. ${ }^{53}$ Satnija koja je bila dodijeljena Nikoli Michieliju Vitturiju u osnovnom je sastavu brojila 60 časnika, dočasnika i vojnika. Časnički odnosno dočasnički kadar činili su zastavnik i kapetanov sin conte Jerolim Franjo Michieli Vitturi, narednici Ivo Vidrić i Jovo Radovan, kaplari Miho Aleksić i Marko Baldissara te kadet Petar Ivan Andrija conte Burović. Kao glazbena pratnja satniji su bili pridodani bubnjar Mate Balić i pifarist Nikola Trišanin. Ostatak satnije činili su obični vojnici (njih 51), od kojih je petnaestak tijekom ovog pratećeg razdoblja prekriženo. Također je potrebno napomenuti da popisivači nisu ni u jednom primjeru uz vojno ljudstvo upisivali podatak o njihovu zavičajnome podrijetlu, iako - na osnovi prezimena (primjerice Batušić, Britvić, Carić, Gabrić, Jurišić, Majstorović, Novaković, Radošević, Šimeša i druga), možemo s gotovo potpunom sigurnošću tvrditi su ovdje prisutni vojnici zavičajem potjecali s istočne obale Jadrana, najvjerojatnije iz Dalmacije i Boke kotorske. U razdoblju od 1789. do 1791. Nikola se bilježi u činu bojnika u pukovniji Nikole Medina koji je - kako se čini - „naslijedio“ dio Knapićevih satnija. ${ }^{54}$ Satnija kojom je bojnik Nikola zapovijedao popisana je 1. rujna 1791., ali je mjesto izrade popisa nepoznato. Broj časnika, dočasnika i vojnika iznosio je 57, a od toga broja naknadno je prekriženo 16 vojnika. Potrebno je i ovdje napomenuti da uz njihova imena ni u jednom primjeru nije navedeno zavičajno podrijetlo, ali je - uzevši u obzir činjenicu da se većina vojnog ljudstva ponavlja u odnosu na prethodni popis - zasigurno njihovo podrijetlo bilo s područja Dalmacije i Boke kotorske. Također, i ovdje se kao zastavnik navodi bojnikov sin Jerolim Franjo Michieli Vitturi.

Vrijednije i uporabljivije podatke o sastavu vojnog ljudstva bojnika Nikole Michielija Vitturija bilježimo na osnovu popisa načinjenog u Hvaru 14. rujna 1791. godine. ${ }^{55}$ Satnija je brojila 47 časnika, dočasnika i običnih vojnika, a naknadno su joj pridodani jedan časnik (potkapetan Antun Alačević),

53 Tada su se u pukovniji Knapić, uz osobnu satniju pukovnika, nalazile satnije kojima su zapovijedali sljedeći časnici: potpukovnici Nikola Zapaga i Giovanni Battista Cristofoli te kapetani Petar Milošević, Lovro Milanović, conte Petar Medin, Marco Antonio Cristofoli i Nikola Maina. Mjesta popisivanja iz izvora nisu jasno razvidna, ali vjerujemo da se radi o Mletcima. Usporedi: ASVe, Inquisitori ... pubblici ruoli. Oltramarini, b. 604A. Reggimento Colonnello Bartolomeo Knapich.

54 U pukovniji Nikole Medina djelovale su tada satnije kojima su zapovijedali sljedeći časnici: potpukovnik Giovanni Battista Cristofoli, kapetani Giacinto Matiazzi, Lovro Milanović, Petar Medin, Marco Antonio Cristofoli i Gabrijel Medin te potkapetan Antun Alačević. Usporedi: ASVe, Inquisitori ... pubblici ruoli. Oltramarini, b. 454. Reggimento Colonnello conte Nicolò Medin.

55 Navedenih su godina u sastavu pukovnije Nikole Medina djelovale satnije predvođene gotovo istim zapovjednicima. Pridodani su samo potpukovnik Matija Filaretto i kapetan Nikola Barbarić. Usporedi: ASVe, Inquisitori ... pubblici ruoli. Oltramarini, b. 651. Reggimento Colonnello conte Nicolò Medin. 


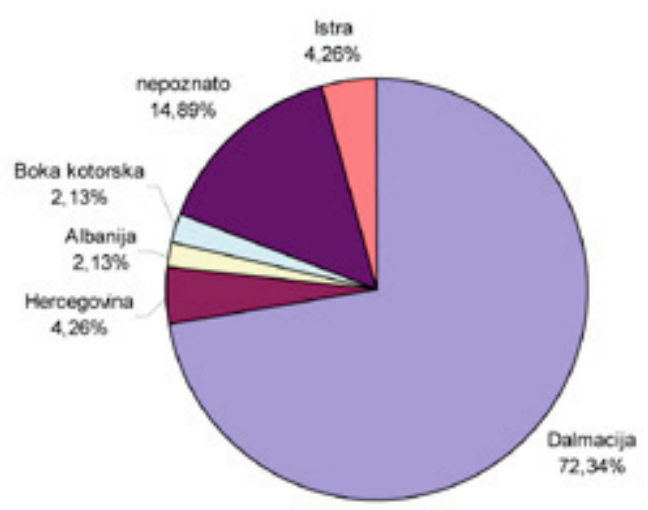

Grafikon 6. Zavičajno podrijetlo vojnog ljudstva u satniji bojnika Nikole Michielija Vitturija prema popisu načinjenom u Hvaru 14. rujna 1791. godine

kadet Spiridion Nikola Ćipiko (Cipico) te dva obična vojnika. Za razliku od prethodnih popisa, ovdje je zavičajno podrijetlo ljudstva uglavnom navedeno te ga je moguće potanko analizirati. Također, u odnosu na prethodni popis ovdje je ljudstvo dijelom promijenjeno, odnosno popunjeno drugim vojnicima, a uz bojnika Nikolu viši vojni kadar činili su zastavnik Jerolim Franjo Michieli Vitturi, narednici Jovo Buzdovan i Ivan Vitrić, kaplari Niko Aleksić i Antun Bortulić, kadet Grgur Dabović, dočim su se u glazbenoj pratnji nalazili bubnjari Anđelo Aleksić i Mate Balić te pifarist Nikola Jajčanin. Zavičajna struktura Nikoline satnije izgledala je ovako (vidi Grafikon 6): prednjačili su Dalmatinci sa $72,34 \%$, a uz vojnike iz većih gradova poput Šibenika, Trogira, Splita i Zadra, ostala mjesta koja se bilježe su Blato na Korčuli, Čiovo, Drniš, Gradac u Promini, Hvar, Imotski, Kaštela, Knin i Pirovac (tada Zlosela). S područja Hercegovine (Mostar) i Istre bilježimo po 4,26 \% ovdje zabilježenih vojnika, dočim su Bokelji i pripadnici postrojbe de Albania zastupljeni sa samo $2,13 \%$. Naposljetku, na osobe nepoznatog (ali kao i u prethodnim primjerima vjerojatno dalmatinskog) podrijetla otpada u odnosu na ukupni broj pripadnika satnije $14,89 \%$ vojnika. ${ }^{56}$

Satnija Nikole Michielija Vitturija bilježi se u pukovniji Medin i sljedeće dvije godine. Tada je naime vojno ljudstvo popisano u Zadru (31. ožujka

56 U prilogu se objavljuje cjelovit popis vojnog ljudstva iz satnije bojnika Nikole Michielija Vitturija načinjen 14. rujna 1791. u Hvaru (vidi Prilog broj 6 na kraju rada). 
1792. i 22. siječnja 1793.), a sastav postrojbe u velikoj je mjeri nalik prethodno analiziranom popisu nastalom u rujnu 1791. godine u Hvaru. ${ }^{57}$ Međutim, već sljedeće godine Nikolina je satnija djelovala u sastavu pukovnije Vicka Michielija Vitturija, a sam Nikola tada se bilježi u činu potpukovnika. ${ }^{58}$ Popisi kojima raspolažemo iz te godine nastali su u Padovi (10. srpnja 1794.) i Mletcima (1. ožujka i 1. rujna 1794.). U primjerima kada su popisi načinjeni u Mletcima satnija je brojila nešto više od trideset vojnika. U odnosu na prethodno analizirani popis (1791.) sastav je vojnika dijelom izmijenjen, ali njihovo zavičajno podrijetlo nije navedeno. ${ }^{59} \mathrm{Za}$ naše je istraživanje mnogo više uporabljiv popis načinjen u ljeto 1794. godine u Padovi, kada je njegov nadređeni rođak Vicko Michieli Vitturi već imao čin pukovnika ${ }^{60}$ Nikolina je satnija tada brojila 69 časnika, dočasnika i običnih vojnika, ${ }^{61}$ od kojih je desetak naknadno prekriženo, a postrojbi je pridodano 11 novih vojnika. U osnovnom sastavu tek je manji broj vojnika zabilježen i u prethodnim popisima (dočasnički je kadar ostao identičan), ali je satnija ipak - radi velikog udjela cernida (ponajviše iz imotskog kraja) - promijenila strukturu ljudstva. Zavičajno podrijetlo ljudstva Nikoline satnije i ovdje je u cjelini odražavalo ukupne omjere iz prethodnih popisa (vidi Grafikon 7). Prevagu su ponovno imali Dalmatinci $(82,61 \%)$, a uz relativno malenu prisutnost vojnika iz većih dalmatinskih gradova (Šibenik, Trogir, Zadar) ili manjih mjesta (Kaštela, Klis, Obrovac, Primošten, Ražanci, Solin, Turanj, Ugljan i druga), opaža se poveća prisutnost cernida iz sela Imotske krajine (Lokvičići, Medov Dolac, Opanci, Podbablje, Poljica, Zagvozd). Iz Istre je u postrojbi potpukovnika Nikole djelovalo 5,80 \% vojnika, Boka (Kotor i Grbalj) je zastupljena s 2,90\%, a Kranjska s 1,45\%. Naposljetku, na vojnike nedefiniranog zavičajnog podrijetla otpadalo je u ukupnom omjeru $7,25 \%{ }^{62}$

57 ASVe, Inquisitori ... pubblici ruoli. Oltramarini, b. 651. Reggimento Colonnello conte Nicolò Medin.

58 ASVe, Inquisitori ... pubblici ruoli. Oltramarini, b. 643. Reggimento Tenente colonnello Vicenzo Michieli Vitturi.

59 (Do)časnički su kadar činili, uz potpukovnika Nikolu još i zastavnik Ivan Nikola Scutari, narednici Špiro Matošević i Stipe Slaković, kaplari Mate Brašić, Atanazije Komazec i Jakov Novakov, a bubnjar je bio Ivan Mikelić.

60 ASVe, Inquisitori ... pubblici ruoli. Oltramarini, b. 644. Reggimento Colonnello conte Vicenzo Michieli Vitturi.

${ }^{61}$ U dočasničkom se dijelu postrojbe bilježe zastavnik Ivan Nikola Scutari, narednici Špiro Matošević i Stipe Slaković, kaplari Mate Brašić, Atanazije Komazec i Jakov Novakov, dočim je u glazbenom dijelu satnije djelovao bubnjar Ivan Mikelić.

${ }^{62} \mathrm{U}$ prilogu se objavljuje cjelovit popis vojnog ljudstva iz satnije potpukovnika Nikole Michielija Vitturija načinjen 10. srpnja 1794. u Padovi (vidi Prilog broj 7 na kraju rada). 


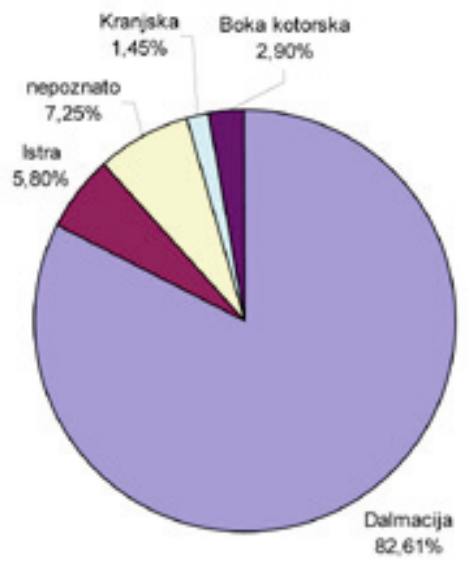

Grafi Kon 7. Zavičajno podrijetlo vojnog ljudstva u satniji potpukovnika Nikole Michielija Vitturija prema popisu načinjenom u Padovi 10. srpnja 1794. godine

Kao i u primjeru Vicka Michielija Vitturija, ni za potpukovnika Nikolu nemamo podatke o posljednjim godinama života. Bitno stariji od bratića Vicka, Nikola je u trenutku nestanka Republike Svetog Marka već bio u poodmaklim godinama i izglednom se čini pretpostavka kako nije nastavio vojnu karijeru. Po svemu sudeći, čin pukovnika nikada nije dosegnuo te možemo pretpostaviti da je vjerojatno preminuo u posljednjim godinama 18 . stoljeća. S članovima obitelji bio je za života tijesno povezan - kao pripadnik pukovnije rečenoga Vicka, ali i činjenicom da je otac Jerolima Franje koji je također stupio u vojnu službu te obnašao čin kapetana mletačkih prekomorskih pješaka na izmaku stoljeća.

Nikolina sina Jerolima Franju u spisima mletačke vojne administracije pronalazimo od 1786. godine kao zastavnika u očevoj satniji koja je tada činila dio pukovnije Bartola Knapića. ${ }^{63}$ Nadalje, 1791. godine Jerolim Franjo je zastavnik u očevoj satniji, ali u sklopu pukovnije Nikole Medina. Također, u svim je primjerima uz njegovo ime pridodan naslov conte. ${ }^{64}$

63 ASVe, Inquisitori ... pubblici ruoli. Oltramarini, b. 604A. Reggimento Colonnello Bartolomeo Knapich.

64 ASVe, Inquisitori ... pubblici ruoli. Oltramarini, b. 651. Reggimento Colonnello conte Nicolò Medin. 
Godine 1796. Jerolim Franjo imao je čin kapetana i bio je zapovjednik satnije u sastavu pukovnije već spomenutog Nikole Medina. ${ }^{65}$ Satnija kapetana Jerolima Franje Michielija Vitturija popisana je u Mletcima na Silvestrovo 1796. godine. U svome je osnovnom sastavu brojila 113 časnika, dočasnika i običnih vojnika, a uz kapetana (do)časnički su dio ljudstva činili još i poručnik (tenente) Nikola Nakić, zastavnik Bernard Šošić (Sošić), narednici Grgo Matijević i Ante Trnovac, kaplari Antun Jovanović, Vicko Kaliterna i Stipan Šoluk, dočim je kao bubnjar ubilježen Jure Martinović. Nekoliko je vojnika preminulo 1796. i 1797. godine te su naknadno prekriženi. Kada je riječ o njihovu matičnom podrijetlu (vidi Grafikon 8), prednjače Dalmatinci $(39,82 \%)$ iz raznih obalnih gradova i mjesta te iz zaleđa. Brojem konkretnih primjera izdvajaju se vojnici s područja Neretve i iz Vrgorca, a ostala su mjesta zabilježena najčešće u pojedinačnim slučajevima (Drniš, Gorica kraj Zadra, Imotski, Kaštel Lukšić, Knin, Makarska, Obrovac, Polača, Rogoznica, Sinj, Skradin, Split, Sukošan, Tisno, Trogir, Turanj i druga). Među njima se, posebno kada je riječ o nešto većem broju vojnika s područja Neretve i iz Vrgorca, zasigurno kriju cernide. Također, dio vojnika (također $39,82 \%$ ) označen je prema pripadnosti postrojbama koje se nazivaju bandiera, odnosno prema njihovim zapovjednicima, pri čemu se vrlo vjerojatno radi o pripadnicima teritorijalnih postrojbi. $S$ obzirom na to da je vrlo teško precizno ustanoviti mjesta njihova podrijetla, u prilogu koji će se objaviti na kraju rada zadržat ćemo naziv bandiera (npr. bandiera Držak, Gulić, Kapitanović i druge). Ipak, za većinu njih možemo s velikom vjerojatnošću pretpostaviti da potječu iz zaleđa Dalmacije, s prostora od zaleđa Zadra do zaleđa Splita. Nadalje, iz Istre je potjecalo $13,27 \%$ vojnika, pri čemu se uz općenitu geografsku oznaku (de Istria) bilježe još i Buzet, Kras (buzetski) i mjesto Grimalda. Nepoznatog je podrijetla (ali bez oznake pripadnosti nekoj od bandiera) upisano 5,31 \% vojnika, dočim na područje Boke kotorske (točnije Paštrovića), kao i na sjevernu Hrvatsku (Lika) otpada po malenih $0,88 \% .{ }^{66}$

O Jerolimu Franji Michieliju Vitturiju također ne znamo podatke o završnim godinama karijere. Zasigurno je njegova postrojba vrlo brzo bila raspuštena, a vojnici - kao i u drugim primjerima - vraćeni u domovinu. Je li Jerolim Franjo

65 U sastavu pukovnije djelovale su, uz osobnu satniju Nikole Medina popisanu u Mletcima 1796., i satnije kojima su zapovijedali potpukovnik Matija Filaretto (Mletci, 1796.) te kapetani Juraj Felicinović (Mletci i Verona, 1796.), Josip Petrović (Mletci, 1796.), Giacomo Matiazzi (Verona, 1796. i Mletci, 1797.), Matija Meštrović (Mletci, 1796.), conte Gabrijel Medin (Mletci, 1796.) i Lovro Milanović (Mletci, 1796.). Usporedi: ASVe, Inquisitori ... pubblici ruoli. Oltramarini, b. 654. Reggimento Colonnello conte Nicolò Medin.

${ }^{66}$ U prilogu se objavljuje cjelovit popis vojnog ljudstva iz satnije kapetana Jerolima Franje Michielija Vitturija, načinjen 31. prosinca 1796. u Mletcima (vidi Prilog broj 8 na kraju rada). 


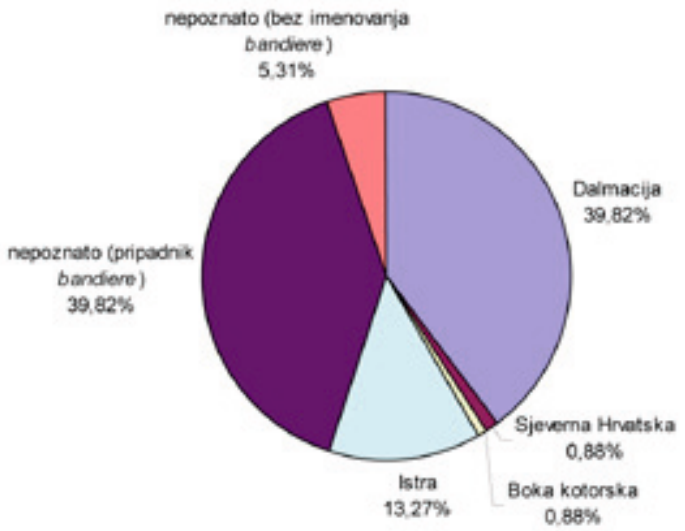

Grafikon 8. Zavičajno podrijetlo vojnog ljudstva u satniji kapetana Jerolima Franje Michielija Vitturija prema popisu načinjenom u Mletcima 31. prosinca 1796. godine

nakon prestanka opstojanja Mletačke Republike umirovljen ili je nastavio vojnu službu, možda će nam otkriti nova istraživanja, ali ona ovom prigodom nisu predmet ovoga rada.

\section{ZAKLJUČAK}

Proučavanje vojne povijesti Dalmacije u 18. stoljeću iziskuje podroban istraživački rad u hrvatskim i u inozemnim pismohranama. $\mathrm{U}$ ovom primjeru korišteno je gradivo pohranjeno u Državnom arhivu u Zadru (Generalni providuri Dalmacije i Albanije, Zbirka tiskovina/stampata i Fond obitelji Zanchi) te ponajprije spisi iz Državnog arhiva u Mletcima (Inquisitori sopra l'amministrazione dei pubblici ruoli). Rečeni spisi pružaju velike mogućnosti za rekonstrukciju vojne karijere časnika i dočasnika zavičajem $s$ istočnojadranske obale. Stoga su u žarištu istraživanja i znanstvene raščlambe ovoga rada odvjetci trogirske plemićke obitelji Michieli Vitturi - pukovnik Vicko (r. 1754.), potpukovnik Nikola (r. 1721.) te kapetan Jerolim Franjo(r. 1755.), mahom prisutni u posljednjim desetljećima i godinama postojanja Mletačke Republike. Svi su oni karijeru započeli u činovima zastavnika i kapetana (zapovjednika pojedinih satnija), a neki od njih s vremenom, vjerojatno na izmaku vojne službe, postigli i više činove te (Vicko) zapovijedali vlastitom pukovnijom. U svim primjerima riječ je o pješačkim jedinicama Oltramarina. Raščlamba popisa vojnog ljudstva koja se ovdje prezentirala pravi je rudnik podataka o strukturi, odnosno ustroju 
onovremenih satnija i pukovnija, a konkretni podatci vezani za časnike, dočasnike i obične vojnike otkrivaju iz kojih su dijelova Istre, Dalmacije, Boke kotorske, ali i krajeva i gradova koji se nisu nalazili pod mletačkom vlašću (primjerice Kranjska, sjeverna Hrvatska) potjecali zabilježeni vojnici. Potrebno je istaknuti kako su satnije, uz profesionalne vojnike, na samom kraju stoljeća popunjavali i pripadnici mletačke teritorijalne milicije (cernide), novačeni poglavito iz manjih mjesta, odnosno najčešće iz dalmatinskog zaleđa, ali i iz Istre (primjer brojnih vojnika iz buzetskog Krasa). U promatranom je razdoblju Mletačka Republika faktički po posljednji puta mobilizirala veći broj ljudstva. Otuda i činjenica da su ovdje predstavljene satnije, upravo zahvaljujući velikom udjelu cernida, brojile i više od stotinu vojnika - pojava koja nije bila uobičajena u klasično mirnodopsko vrijeme. Sudbina tih vojnika i njihovih postrojbi u konačnici nije nam poznata, ali je vjerojatno da su s vremenom raspuštene, a ljudstvo poslano u domovinu. U svakom slučaju vjerujemo da je ovaj prilog dodatan prinos poznavanju same obitelji Michieli Vitturi, ali i udjela (pretežito) hrvatskih vojnika u mletačkim prekomorskim pješačkim postrojbama. Naposljetku, grafički pregledi koji se donose, kao i konkretni popisi časnika, dočasnika i vojnika u satnijama Vicka, Nikole i Jerolima Franje Michielija Vitturija - objavljivanjem njihovih imena i prezimena te zavičajnog podrijetla - dodatan su prinos za proučavanje niza hrvatskih mikroregionalnih sredina. 
Prilog 1. Satnija kapetana Vicka Michielija Vitturija u sastavu pukovnije Marka Ginnija, popisana između 1774. i 1779. godine (Archivio di Stato di Venezia, Inquisitori sopra l'amministrazione dei pubblici ruoli. Oltramarini, b. 604A. Reggimento Colonnello Marco Ginni. Compagnia Capitan Vicenzo Michieli Vitturi)

1. Kapetan (Capitan): Vicko Michieli Vitturi

2. Dokapetan (Capitan tenente): Marko Antun Scutari

3. Zastavnik (Alfier): Nikola Knapić

4. Zastavnik (Alfier): Petar Vidali

5. Narednik (Sargente): Petar Atlagić - Grgo - Drniš

6. Narednik (Sargente): Frane Bilas - Petar - Kaštel Stari

7. Narednik (Sargente): Pietro Bittuari

8. Narednik (Sargente): Nikola Bosnić

9. Narednik (Sargente): Jure Čipčić

10. Narednik (Sargente): Dimo Janšić - Miho - Istra

11. Narednik (Sargente): Blaž Lupšić

12. Narednik (Sargente): Andrija Sliperić

13. Narednik (Sargente): Frane Zadrić - Petar - Dubrovnik

14. Bubnjar (Tamburo): Ivan Krstitelj Bravazzo - Istra

15. Bubnjar (Tamburo): Antun Garetić

16. Bubnjar (Tamburo): Antun Šimera

17. Bubnjar (Tamburo): Anđelo Valentinić

18. Bubnjar (Tamburo): Tadija Visinine

19. Bubnjar (Tamburo): Ivan Zadrić

Vojnici (Soldati):

20. Bastijan Bačerić - Miho - Herceg Novi

21. Frane Barić

22. Jovo Begović

23. Ivan Berket - Dalmacija

24. Risto Besenić - Nikola

25. Vicko Biauna

26. Antun Bilosin

27. Aleksije Bornić

28. Ivan Branković

29. Jakov Branković

30. Antun Busko

31. Federik Caratan

32. Martin Cerenja

33. Mate Cerir

34. Sebastijan Costa - Petar - Istra

35. Petar Craizar - Antun

36. Rinaldo Damjanović 
37. Jure Dobrilović (Dobrovac) - Mate - Istra

38. Nikola Dobrilović (Dobrovac) - Mate - Istra

39. Dume Dobrovrime - Fran - Istra

40. Jure Drašković

41. Mate Dugarić - Ivan - Istra

42. Nikola Dujmović - Ivan - Herceg Novi

43. Mate Eršić - Ivan - Brač

44. Nikola Glaminić - Antun - Brač

45. Jure Gorica

46. Ilija Grljanac - Marko - Dalmacija

47. Mate Ivanković - Nikola - Sinj

48. Antun Janović

49. Jure Jelušić

50. Antun Jeretić

51. Ivan Jurišić

52. Andrija Kalić

53. Mate Karamanović

54. Ambroz Karbarević

55. Marko Karlović

56. Šime Ledić - Grgur - Pazin

57. Antun Ligna (de)

58. Toma Lipur

59. Gerolimo Lombardo

60. Luka Lučić - Petar - Ogorje

61. Jakov Lungruga

62. Frane Lušić

63. Stipan Maranić - Ilija - Zagora

64. Franjo Matan - Mate - Kotor

65. Ivan Medin

66. Ivan Medinjak - Mijat - Klis

67. Josip Mesarić

68. Zorzi Messina

69. Antun Milanović - Bastijan - Istra

70. Bariša Miljak - Stipan - Petrovo polje

71. Petar Mirić - Vicko - Kaštela

72. Mate Morović

73. Antun Odak - Antun - Kaštela

74. Jure Panković - Antun - Šibenik

75. Jakov Pekas

76. Mate Perčić - Antun

77. Antun Pletković - Ivan - Zagora

78. Stojan Radov - Rado - Kotor

79. Stipan Rosanović - Mate - Kaštela

80. Ivan Rudović 


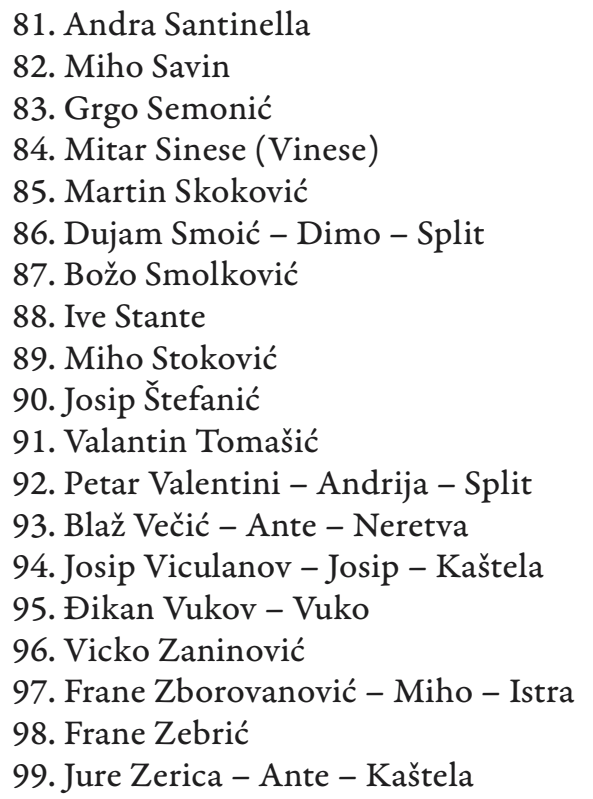

Prilog 2. Satnija potpukovnika Vicka Michielija Vitturija u sastavu pukovnije Nikole Scutarija, popisana u Zadru 31. kolovoza 1789. (Archivio di Stato di Venezia, Inquisitori sopra l'amministrazione dei pubblici ruoli. Oltramarini, b. 701. Reggimento Colonnello Nicolò Scutari. Compagnia Tenente colonnello conte Vicenzo Michieli Vitturi)

1. Potpukovnik (Tenente colonnello): conte Vicko Michieli Vitturi

2. Zastavnik (Alfier): Antun Fabijan Scutari

3. Narednik (Sargente): Mate Fališić - Jakov

4. Narednik (Sargente): Lovro Matošević - Jure - Zadar

5. Kaplar (Caporal): Lovre Bilanović - Ivo - Trogir

6. Kaplar (Caporal): Ivan Bratulić - Jure - Zadar

7. Kaplar (Caporal): Mate Trustić - Vicko - Kaštela

8. Kadet (Cadetto): Carlo Giuseppe Bontempo - Bernardo ${ }^{67}$

9. Kadet (Cadetto): Giacomo Antonio Dibri ${ }^{68}$

10. Bubnjar (Tamburo): Luka Kišević - Krsto - Crna Gora

11. Pifarist (Piffaro): Nikola Bratulić - Ivan - Zadar

67 Naveden je datum njegova rođenja: 13. siječnja 1762.

68 Navedeno je da je sin zaslužnika (benemerito) dokapetana (Capitan tenente) Marca. Kadet je rođen 11. studenoga 1770 . 
Vojnici (Soldati):

12. Ivan Bastić - Ivan - Islam

13. Jerko Bašić - Ivan - Pag

14. Toma Bijančić - Josip - Zadar

15. Toma Deković - Šimun - Rogoznica

16. Mate Dević - Vicko - Petrovo polje

17. Grgo Dondošić - Jakov - Radovin

18. Dujam Fantinović - Andrija - Split

19. Šime Fatović - Ivan - Kukljica

20. Matija Franković - Andrija - Split

21. Grgo Gabrić - Antun - Murter

22. Ivan Grginović - Šimun - Sukošan

23. Stipan Grubišić - Antun - Pag

24. Ivan Jurišić - Niko - Skradin ${ }^{69}$

25. Jadre Korić - Jakov - Bibinje

26. Dominik Koza (Coza) - Lovre - Istra

27. Gajo Martinović - Dragiša - Kula Atlagića $a^{70}$

28. Špiro Matošević - Lovre - Poljica

29. Josip Milinov - Josip - Trogir

30. Petar Milović - Stjepan - Kula Atlagića

31. Matija Morović - Mihovil - Islam

32 Andrija Njeglić - Frane - Pula

33. Luka Opačić - Ilija - Bukovica

34. Matija Orazza - Ivan - Šibenik

35. Vicko Papić - Nikola - Vis

36. Mijo Pones (Ponoš) - Jure - Dugopolje

37. Toma Prijak - Gašpar - Murter

38. Ivo Rabadan - Jakov - Kaštel Lukšić

39. Toma Solomanić - Toma - Dalmacija

40. Luka Šarlija - Antun - Obrovac

41. Jerko Škulja - Grgo - Biljane ${ }^{71}$

42. Luka Španja - Antun - Šibenik

43. Šime Vidović - Josip - Pag

44. Ivan Vrbić - Petar - Rodaljice

45. Mate Zulavić - Ivan - Šibenik

46. Jerko Žurović - Petar - Dalmacija

Naknadno dopisani vojnici:

1. Grgo Đačić - Andrija

2. Giosef Gison - Andrija - Gorizia - 24 - visok - smeđokos

3. Pavao Kovačić - Jerko - Istra - 18 - srednjeg rasta - smeđokos

69 Dezertirao te je naknadno prekrižen s popisa.

70 Dezertirao te je naknadno prekrižen s popisa.

71 Dezertirao te je naknadno prekrižen s popisa. 
4. Mate Lovrić - Ivan - Rogoznica - 22 - srednjeg rasta - smeđokos

5. Martin Miočević - Petar

6. Andrija Muggia - Gajo - Ceslovac (?) - 18 - srednjeg rasta - smeđokos

7. Franjo Offman - Jure - Trst - 25 - srednjeg rasta - smeđokos

8. Stipe Perina - Marko - Tisno - 22- srednjeg rasta - smeđokos

9. Šime Pones (Ponoš) - Jure - Dugopolje - 18- srednjeg rasta - smeđokos

10. Petar Radica - Nikola - Karin - 18 - srednjeg rasta - smeđokos

11. Aleksa Trifunović - Jakov - Risan - 24 - srednjeg rasta - smeđokos

12. Jakov Vidoslavić - Ilija - Skradin - 21 - srednjeg rasta - smeđokos

Prilog 3. Popis naknadno prispjelih vojnika i cernida u osobnoj satniji pukovnika Vicka Michielija Vitturija prema popisu načinjenom 29. rujna 1793. u Mletcima (Archivio di Stato di Venezia, Inquisitori sopra l'amministrazione dei pubblici ruoli. Oltramarini, b. 644. Reggimento Colonnello conte Vicenzo Michieli Vitturi)

1 Kaplar (Caporal): Stipan Udiljak - Frane - Studenci ${ }^{72}$

2. Bubnjar (Tamburo): Šime Bassan - Ivan - Zadar

3. Pifarist (Piffaro): Marko Jakina - Jure - Šibenik

4. Jure Bandić - Marko - Grabovac

5. Martin Bartulović - Andrija - Studenci

6. Matija Basanese - Jakov ${ }^{73}$

7. Ivan Beršić - Stipan - Grabovac

8. Ilija Biondić - Marko - Svib

9. Ilija Brdar - Tripun - Svib

10. Joviša Carić - Jovan - kninsko područje (territorio di Knin)

11. Ivan Draščić - Jovo - kninsko područje (territorio di Knin)

12. Abram Erak - Joka - kninsko područje (territorio di Knin)

13. Ante Galić - Stipan - Svib

14. Nikola Galić - Andrija - Svib

15. Mate Grmak - Jakov ${ }^{74}$

16. Petar Grubiša - Antun - Sinj

17. Ante Jelanov - Bono - Zagora

18. Ilija Jelić - Lazar - Zadar ${ }^{75}$

19. Frane Malas - Sava - Zadar

20. Jakov Mandić - Šibenik

21. Blaž Manitić - Filip - Grabovac

72 Naknadno prekrižen.

73 Naknadno prekrižen.

74 Naknadno prekrižen.

75 Naknadno prekrižen. 
22. Jure Manitić - Grgo - Grabovac

23. Gajo Matijašević - Petar - kninsko područje (territorio di Knin)

24. Gašpar - Matko - Petar

25. Nikola Medić - Petar - kninsko područje (territorio di Knin)

26. Mate Milešić - Mate - Studenci

27. Ivan Milić - Josip - Šibenik

28. Mihovil Perović - Martin

29. Mate Porta - Ivan - Studenci

30. Lovre Primović - Bože - Grabovac

31. Marijan Primović - Toma - Grabovac

32. Antun Prinčić - Josip ${ }^{76}$

33. Mihovil Prinčić - Josip ${ }^{77}$

34. Antun Rabadanović - Ivan - Trogir

35. Antun Rastapić - Marko - Grabovac

36. Lazo Renjetović - Ilija - kninsko područje (territorio di Knin)

37. Joviša Simić - Gajo - kninsko područje (territorio di Knin)

38. Cvitko Stiparić - Petar - Studenci

39. Pave Škarica - Šime - kninsko područje (territorio di Knin)

40. Augustin Trogrlić - Mate - Studenci

41. Mate Trogrlić - Augustin - Studenci

42. Miho Trogrlić - Petar - Studenci ${ }^{78}$

43. Miho Udovičić - Stipan - Studenci

44. Jovo Urukalo - Jovo - kninsko područje (territorio di Knin)

45. Ivan Vranković - Todor - kninsko područje (territorio di Knin)

46. Mate Žepina - Ivan

Prilog 4. Osobna satnija pukovnika Vicka Michielija Vitturija, prema popisu načinjenom u Mletcima 31. prosinca 1796. godine (Archivio di Stato di Venezia, Inquisitori sopra l'amministrazione dei pubblici ruoli. Oltramarini, b. 646. Reggimento Colonnello conte Vicenzo Michieli Vitturi)

1. Pukovnik (Colonnello): conte Vicko Michieli Vitturi

2. Zastavnik (Alfier): Lovro Matošević - Jure - Zadar

3. Narednik (Sargente): Vicko Ković - Jakov - Kaštela

4. Narednik (Sargente): Ivo Rabadan - Jakov - Kaštel Lukšić

5. Kaplar (Caporal): Mate Balić - Božo - Klis

6. Kaplar (Caporal): Filip Divić - Ilija

7. Kaplar (Caporal): Bajo Reić - Marko - Klis

8. Kaplar (Caporal): Antun Vojnić - Ivan - Pula

76 Naknadno prekrižen.

77 Naknadno prekrižen. 
9. Kadet (Cadetto): Ivan Krstitelj Antun Arnerić - Franjo

10. Bubnjar (Tamburo): Šime Basan - Ivan - Zadar

Vojnici (Soldati):

11. Antun Alfirović - Dujam - Kaštel Sućurac

12. Pavao Alfirović - Ivan - Kaštel Sućurac

13. Ilija Bajić - Luka ${ }^{79}$

14. Mijo Baković - Marko - Banjevci

15. Mihajlo Ban - Aleksa - Gornja Jagodnja

16. Kristijan Barada - Mate - Banjevci

17. Dominik Belinić - Benedikt - Istra

18. Marko Berić (Bernić) - Gašpar - Istra

19. Josip Berković - Brne - Banjevci

20. Šime Berković - Jakov - Banjevci

21. Juraj Bolan - Frane - Istra

22. Antun Bonić - Grgo - Buzet

23. Antun Bonić - Mate - Buzet

24. Antun Božić - Jakov - Kras

25. Mate Božić - Lovre - Kras

26. Antun Brajković - Jure - Kras

27. Mihovil Brajković - Matija - Kras

28. Grgur Bratelić - Miko - Kras

29. Petar Bratinčević - Frane

30. Antun Budiša - Jakov - Kras

31. Stipe Bušić - Antun - Kras

32. Mate Casella - Bastijan - Istra

33. Pavao Cerin - Mate - Kras

34. Grgur Clui - Grgur - Kras

35. Miho Čelan - Ante - bandiera Brstilo

36. Petar Čelanović - Miho - Makarska ${ }^{80}$

37. Grgur Činčić - Ivan - Istra

38. Petar Čiošić (Chiosich) - Mihajlo ${ }^{81}$

39. Frane Damjanov - Jerolim - Kaštel Gomilica

40. Jakov Divić - Ilija ${ }^{82}$

41. Stjepan Dotinić - Toma - Makarska

42. Luka Dratazović - Nikola - Kaštela

43. Grgur Duban - Stjepan - Istra

44. Mihovil Furlan - Pave - Šibenik

45. Jure Gačenić - Frane - Makarska

78 Naknadno prekrižen.

79 Naknadno prekrižen.

80 Naknadno prekrižen.

81 Naknadno prekrižen.

82 Preminuo 3. lipnja 1797. te je prekrižen. 
46. Mate Gelija - Grgur - Istra ${ }^{83}$

47. Matija Gregac - Mate - Istra

48. Luka Grubač (Grubas) - Mihovil - Kras

49. Lazo Grubić - Ivan - Gornja Jagodnja

50. Petar Gulić - Mihajlo - Gornja Jagodnja

51. Jakov Ivančić - Ivan - Kras

52. Ilija Jelić - Lazar

53. Jure Karamanović - Stipan - Zadar

54. Antun Katurinčić - Stane - Istra

55. Josip Klarić - Matija - Istra

56. Luka Klarić - Mihovil - Kras

57. Mate Klobaš (Clobas) - Grgur - Kras

58. Petar Kokotović - Miko - Kotor

59. Martin Konzolac (Conzolaz) - Ivan - Istra

60. Mate Kostešić - Jure - Pula

61. Šimun Kovač - Jure - Kaštel Sućurac

62. Antun Krizmanić - Mihovil - Kras

63. Šimun Lalić - Stipan - zadarsko okružje (contado di Zara)

64. Ante Lemić - Martin - Pristeg

65. Antun Lemas - Šime - Kras

66. Jakov Lestić - Laghe (?) - Krajina

67. Juraj Lorenzin - Antun - Istra

68. Antun Lubinac - Antun - Istra

69. Antun Majić - Martin - Kras

70. Mate Mandić - Nikola - Imotski

71. Jure Manitić - Grgo - Grabovac

72. Ivan Marijan - Nikola - zadarsko okružje (contado di Zara)

73. Mihovil Marinović - Mihovil - Kaštel Sućurac

74. Antun Matijašić - Toma - Istra

75. Josip Matikurvić - Mate - Trogir

76. Gašpar Matko - Petar - Kranjska ${ }^{84}$

77. Grgo Mikas - Miko - Kras

78. Ive Mikas - Jure - Kras

79. Jakov Mikas - Antun - Kras

80. Ante Milešić - Mate - Studenci ${ }^{85}$

81. Petar Mišina - Petar - Kaštel Kambelovac

82. Ivan Odak - Nikola - bandiera Nakić

83. Josip Ofkorac - Mijat ${ }^{86}$

84. Antun Paraga - Mate - Kras

85. Matija Pastorić - Mate - Istra

83 Preminuo 2. veljače 1797. te je prekrižen.

84 Naknadno prekrižen.

85 Naknadno prekrižen.

86 Naknadno prekrižen. 
86. Gašpar Pasudel - Ivan - Kras

87. Frane Pavat - Grgur - Istra

88. Ivan Piloto - Stjepan - Istra

89. Ivan Poropat - Antun - Kras

90. Jure Poropat - Antun - Kras

91. Šime Poropat - Matija - Kras

92. Martin Poropat - Luka - Kras

93. Mate Požar - Jure - Rupe

94. Luka Prisko - Matija - Kras

95. Antun Rabadanović - Ivan - Trogir ${ }^{87}$

96. Frane Raretić - Frane - Split

97. Jakov Rašić - Stipe - Kras

98. Marko Sanković - Marko - Buzet

99. Matija Segato - Blaž - Istra

100. Antun Serčić - Matija

101. Antun Skonić - Ivan - Šibenik

102. Petar Slučić ${ }^{88}$

103. Lazo Smirić - Todor - Gornja Jagodnja

104. Stipan Svilanov - Jure - Kaštela

105. Ivan Šarić - Šimun - Banjevci

106. Pave Šarić - Vid - Banjevci

107. Stevan Šaulica - Jure - Gornja Jagodnja

108. Šime Škaranović - Mate - Trogir

109. Mitar Šošić - Jovo - Šibenik

110. Matija Šparko (Sparko) - Bastijan - Kras

111. Miko Šverko - Jure - Kras

112. Stipe Šverko - Ive - Kras

113. Blaž Troskot - Ante - Banjevci

114. Stipan Troskot - Nikola - Banjevci

115. Toma Troskot - Ante - Banjevci

116. Grgur Ušić - Toma - Istra

117. Antun Vidošević - Stipan - Šolta

118. Marko Zimić - Pero - Rovinj

119. Grgur Zlodić - Blaž - Kras

120. Marko Zolović (Colović) - Filip - bandiera Nakić

Naknadno dopisani:

1. Pifarist (piffaro): Antun Armano - Andrija - Dalmacija - 15

2. Ivan Bradić - Antun - Istra

3. Petar Mirić - Vicko - Kaštela

4. Stjepan Pilat - Stjepan - Istra

87 Naknadno prekrižen.

88 Naknadno prekrižen. 
Prilog 5. Dopis generalnog providura Dalmacije i Albanije Francesca Faliera o imenovanju Nikole Michielija Vitturija u čin bojnika, napisan u Kotoru 1. srpnja 1786. (Državni arhiv u Zadru, Generalni providuri Dalmacije i Albanije, Francesco Falier, 1784. - 1786., kut. 201, fol. 287-287v)

\section{Serenissimo Prencipe}

Per non essersi potuto verificare le prove di Sargente maggiore nel Reggimento Knapich de Fanti Oltramarini disperso nelle diverse esigenze di queste Provincie, da quando fù promosso in Tenente collonello il Sargente maggiore Donà e leva restò fin ad'ora vacante il grado medessimo abilitato dall' indulto Clementissimo di Vostra Serenità spiegato nel recento Decreto 18 Maggio decorso il Capitan Nicolò Michieli Vitturi, a poter riempire il vacuo predetto senza sottostare a nuovi cimenti di prove, dopo di aver corrisposto alle medessime con distinta abilità ne due ultimi incontri nell'anno 1768 in codesto Lido, ed a Corfù nel 1775 come lo comprovano le esistenti fedi in desto Offizio dell'Eccellentissimo Savio alla Scrittura, ha creduto quindi questa carica di dover devenire alla promozione dello stesso in Sargente maggiore e di rassegnare all'Eccellentissimo Senato cogli attestati di sua subbordinazione, il presente riverente cenno, affinchè venghi aualorati dei Pubblici Sovrani beneplaciti. Grazie.

Cattaro, il primo Luglio 1786.

Prilog 6. Satnija bojnika Nikole Michielija Vitturija, prema popisu načinjenom u Hvaru 14. rujna 1791. godine (Archivio di Stato di Venezia, Inquisitori sopra l'amministrazione dei pubblici ruoli. Oltramarini, b. 651. Reggimento Colonnello conte Nicolò Medin. Compagnia Sargente maggiore conte Nicolò Michieli Vitturi)

1. Bojnik (Sargente maggiore): conte Nikola Michieli Vitturi

2. Zastavnik (Alfier): conte Jerolim Franjo Michieli Vitturi

3. Narednik (Sargente): Jovo Buzdovan

4. Narednik (Sargente): Ivan Vitrić - Petar - Kaštela

5. Kaplar (Caporal): Niko Aleksić - Jovo

6. Kaplar (Caporal): Antun Bortulić - Jakov - Kaštel Lukšić

7. Kadet (Cadetto): Grgur Dabović ${ }^{89}$

8. Bubnjar (Tamburo): Anđelo Aleksić - Niko ${ }^{90}$

9. Bubnjar (Tamburo): Mate Balić - Pave - Kaštela

10. Pifarist (Piffaro): Nikola Jajčanin - Mate - Drniš

89 Dopisano da se trenutno attrova negli studi.

90 Dopisano da je sin kaplara Nike. 


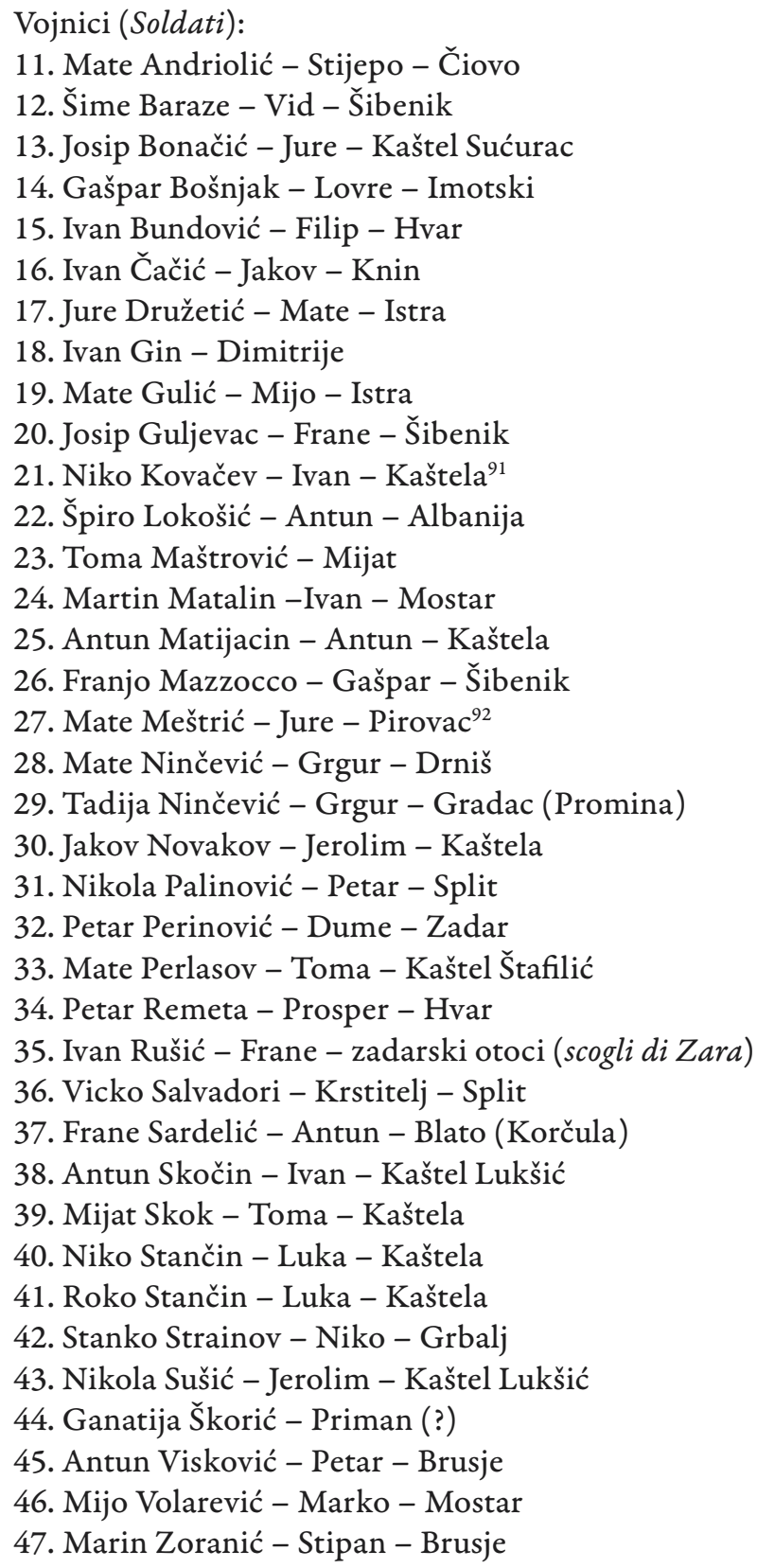

Vojnici (Soldati):

11. Mate Andriolic - Stijepo - Ciovo

12. Šime Baraze - Vid - Šibenik

13. Josip Bonačić - Jure - Kaštel Sućurac

14. Gašpar Bošnjak - Lovre - Imotski

15. Ivan Bundović - Filip - Hvar

16. Ivan Čačić - Jakov - Knin

17. Jure Družetić - Mate - Istra

18. Ivan Gin - Dimitrije

19. Mate Gulić - Mijo - Istra

20. Josip Guljevac - Frane - Šibenik

21. Niko Kovačev - Ivan - Kaštela ${ }^{91}$

22. Spiro Lokošić - Antun - Albanija

23. Toma Maštrović - Mijat

24. Martin Matalin -Ivan - Mostar

25. Antun Matijacin - Antun - Kaštela

26. Franjo Mazzocco - Gašpar - Šibenik

27. Mate Meštrić - Jure - Pirovac ${ }^{92}$

8. Mate Ninčevic - Grgur - Drniš

29. Tadija Ninčević - Grgur - Gradac (Promina)

30. Jakov Novakov - Jerolim - Kaštela

1. Nikola Palinović - Petar - Split

32. Petar Perinović - Dume - Zadar

33. Mate Perlasov - Toma - Kaštel Štafilić

34. Petar Remeta - Prosper - Hvar

35. Ivan Rušić - Frane - zadarski otoci (scogli di Zara)

36. Vicko Salvadori - Krstitelj - Split

37. Frane Sardelić - Antun - Blato (Korčula)

38. Antun Skočin - Ivan - Kaštel Lukšić

99. Mijat Skok - Toma - Kaštela

40. Niko Stančin - Luka - Kaštela

41. Roko Stančin - Luka - Kaštela

2. Stanko Strainov - Niko - Grbalj

43. Nikola Sušić - Jerolim - Kaštel Lukšić

44. Ganatija Škorić - Priman (?)

45. Antun Visković - Petar - Brusje

47. Marin Zoranić - Stipan - Brusje

91 Dezertirao te je prekrižen.

92 Ondašnja Zlosela. 
Naknadno dopisani:

1. Potkapetan (Capitan tenente): Antun Alačević

2. Kadet (Cadetto): Spiridion Nikola Ćipiko

3. Antun Mihović - Jure - Karin

4. Josip Vidić - Ivan - Makarska

Prilog 7. Satnija potpukovnika Nikole Michielija Vitturija, prema popisu načinjenom u Padovi 10. srpnja 1794. godine (Archivio di Stato di Venezia, Inquisitori sopra l'amministrazione dei pubblici ruoli. Oltramarini, b. 644. Reggimento Colonnello conte Vicenzo Michieli Vitturi. Compagnia Tenente colonnello conte Nicolò Michieli Vitturi)

1. Potpukovnik (Tenente colonnello): conte Nikola Michieli Vitturi

2. Zastavnik (Alfier): Ivan Nikola Scutari

3. Narednik (Sargente): Špiro Matošević - Lovre

4. Narednik (Sargente): Stipe Slaković - Vuko

5. Kaplar (Caporal): Mate Brašić - Marko - Ražanci

6. Kaplar (Caporal): Atanazije Komazec - Ivan - Korlat

7. Kaplar (Caporal): Jakov Novakov - Jerolim - Kaštela

8. Bubnjar (Tamburo): Ivan Mikelić - Toma - Solin

Vojnici (Soldati):

9. Nikola Aldak - Nikola

10. Petar Arat - Anđelo - Istra

11. Mate Balić - Pave - Kaštela ${ }^{93}$

12. Ivan Bravarović - Josip - Kotor

13. Rade Brstilo - Vid - Medov Dolac

14. Luka Crnatić - Mate - Solin

15. Antun Čagalj (Cingal) - Mate - Medov Dolac

16. Petar Ćapin - Marko - Podbablje

17. Ivan Drača - Arsenije - Biljane

18. Martin Granić - Marko - Medov Dolac

19. Mate Granić - Antun - Medov Dolac

20. Marin Grlja (Gherlia) - Frane - Šibenik

21. Mate Gulić - Miho - Istra

22. Nikola Ivirović - Josip - Opanci

23. Mate Janković - Ive - Ugljan ${ }^{94}$

24. Tadija Jelić - Antun - Opanci

93 Naknadno prekrižen.

94 Naknadno prekrižen. 
25. Jakov Jurić - Jure - Lokvičići

26. Miho Jurić - Frane - Lokvičići

27. Gajetan Kanjenak - Vid - Istra

28. Blaž Katić - Lovre - Lokvičići

29. Josip Komarić - Šime - Turanj

30. Mate Komarić - Josip - Turanj

31. Ivan Kontić/Konžić - Miho - Poljica (imotska)

32. Jure Lončar - Luka - Zagvozd

33. Antun Lošić - Šimun - Poljica (imotska)

34. Filip Lučina - Nikola - Zadar ${ }^{95}$

35. Grgo Lušić - Marijan - Lokvičići

36. Nikola Lušić - Jerolim - Kaštel Lukšić ${ }^{96}$

37. Stjepan Maestrin - Andrija - Kranjska ${ }^{97}$

38. Jakov Margeta - Grgo - Poljica (imotska)

39. Andrija Marić - Stipan - Lokvičići

40. Marko Marina - Jure - Primošten ${ }^{98}$

41. Gašpar Marinović - Mijat - Primošten

42. Marin Marochia - Stipan - Šibenik

43. Mate Matković - Ivan - Medov Dolac

44. Nikola Matković - Stipan - Medov Dolac

45. Šime Mazucato - Petar - Šibenik ${ }^{99}$

46. Josip Miloš - Petar - Podbablje

47. Mate Parisi - Ante - Drvenik Veli

48. Miho Perić - Stipan - Podbablje

49. Stipan Perušić - Vice - Podbablje

50. Jure Petrović - Mate - Zadar

51. Jure Piplica - Luka - Medov Dolac

52. Mate Piplica - Stipan - Zagvozd

53. Marin Rako - Bariša - Zagvozd

54. Toma Risković - Pave

55. Jure Rokov - Mitar - Obrovac

56. Frane Skender - Šimun - Zagvozd

57. Miho Skender - Vid - Zagvozd

58. Ilija Smolčić - Ilija - Lokvičići

59. Mijat Stramotić - Ivan - Gorizia ${ }^{100}$

60. Jure Sudec - Toma - Poljica (imotska)

61. Pavao Svilinović - Andrija - Opanci

95 Dezertirao te je prekrižen.

96 Naknadno prekrižen.

97 Dezertirao te je prekrižen.

98 Naknadno prekrižen.

99 Naknadno prekrižen.

100 Naknadno prekrižen. 
62. Jure Šućur - Šimun - Podbablje

63. Grgo Šušnjar - Toma - Poljica (imotska)

64. Blaž Tolić - Jure - Podbablje

65. Nikola Vodanović - Bartol - Brač ${ }^{101}$

66. Mate Volić - Ive - Grbalj ${ }^{102}$

67. Andrija Vrljačić - Jakov - Poljica (imotska)

68. Toma Vujanić - Jure - Poljica (imotska)

69. Marko Vuković - Miho - Klis

Naknadno dopisani vojnici:

1. Ivan Baljević - Juraj

2. Ivan Bora - Nikola

3. Juraj Franić - Antun

4. Josip Insir - Luka

5. Antun Ivačić - Petar

6. Šimun Mađerac - Sava

7. Nikola Manzin - Gajo

8. Ilija Mazan - Antun

9. Martin Ramčić - Matija

10. Toma Vrljak - Ilija

11. Vid Žutić - Marijan

Prilog 8. Satnija kapetena Jerolima Franje Michielija Vitturija prema popisu načinjenom u Mletcima 31. prosinca 1796. godine (Archivio di Stato di Venezia, Inquisitori sopra l'amministrazione dei pubblici ruoli. Oltramarini, b. 654 . Reggimento Colonnello conte Nicolò Medin. Compagnia Capitano conte Girolamo Francesco Michieli Vitturi)

1. Kapetan (Capitan): Jerolim Franjo Michieli Vitturi

2. Poručnik (Tenente): Nikola Nakić

3. Zastavnik (Alfier): Bernard Šošić (Sošić)

4. Narednik (Sargente): Grgo Matijević - Frano

5. Narednik (Sargente): Ante Trnovac - Ivan - Obrovac

6. Kaplar (Caporal): Toma Donić - Grgo - bandiera Držak (Derzach)

7. Kaplar (Caporal): Antun Jovanović - Mate - Lika

8. Kaplar (Caporal): Vicko Kaliterna - Dujam - Split

9. Kaplar (Caporal): Stipan Šoluk - Ivan - Vrgorac

10. Bubnjar (Tamburo): Jure Martinović - Luka - Paštrovići

101 Preminuo 3. rujna 1794. te je naknadno prekrižen.

102 Dezertirao te je prekrižen. 
Vojnici (Soldati):

11. Mile Adžić - Pere - Gorica (kraj Zadra)

12. Križan Antunović - Martin - Vrgorac

13. Marko Babić - Petar - Neretva

14. Luka Barbir - Jure - Sinj

15. Josip Barešić - Petar - Drvenik Veli

16. Jakov Bašić - Jure - bandiera Kapitanović

17. Ivan Beg - Ivan - bandiera Gulić

18. Matija Bembrić - Antun - Istra

19. Jakov Benčina - Ivan - bandiera Kapitanović

20. David Berić - Mihajlo ${ }^{103}$

21. Ivan Crivellari - Bernard - Skradin

22. Matija Cukor - Mihovil - Istra ${ }^{104}$

23. Blaž Curian - Antun - Istra

24. Andrija Cvitanović - Luka - Neretva

25. Mihovil Čudina - Jakov - bandiera Držak (Derzach)

26. Ivan Dabnin - Ivan - bandiera Gulić

27. Grgur Daković - Dujam - bandiera Kapitanović

28. Matija Daković - Antun - bandiera Kapitanović

29. Ivan Darkan - Antun - bandiera Držak (Derzach)

30. Antun Darovac - Andrija - Neretva

31. Ivan Dolić - Ilija - Neretva

32. Ivan Dondo - Josip - Kras

33. Mate Dragović - Mihovil

34. Martin Dubić - Martin - Istra

35. Jakov Đečić (Giecich) - Dujam - bandiera Kapitanović

36. Stipan Erceg - Ivan - Neretva

37. Blaž Filipović - Nikola - bandiera Kapitanović ${ }^{105}$

38. Tadija Filipović - Antun - bandiera Kapitanović

39. Antun Grišan - Šime - Strmica

40. Stipan Guberac - Ivan - bandiera Držak (Derzach) $)^{106}$

41. Jakov Gučić - Jakov - bandiera Kapitanović ${ }^{107}$

42. Matija Gučić - Šimun - bandiera Kapitanović

43. Toma Ivan (Zuan) - Ivan - bandiera Kapitanović

44. Matija Jajić - Filip - bandiera Držak (Derzach)

45. Marko Jakić - Grgo - bandiera Gulić

46. Josip Jelašić - Ivan - Vrgorac

103 Preminuo 31. siječnja 1797. te je naknadno prekrižen.

104 Preminuo 28. prosinca 1796. te je prekrižen.

105 Preminuo 10. siječnja 1797. te je naknadno prekrižen.

106 Preminuo 2. ožujka 1797. te je naknadno prekrižen.

107 Preminuo 2. ožujka 1797. te je naknadno prekrižen. 
47. Antun Jurišić - Mate - Grimalda

48. Andrija Kaliterna - Dujam - Split

49. Juraj Katinović - Ivan - Neretva

50. Mate Kernić - Ante - bandiera Držak (Derzach)

51. Josip Kokot - Mihovil - Istra

52. Šime Kos - Ivan Marija - Istra

53. Ivan Kovačević - Milo - Gorica (kraj Zadra)

54. Martin Kranjac - Mate - Tisno

55. Ante Kunešić - Matija - Zagora

56. Marko Kurbaša (Curobasso) - Matija - bandiera Kapitanović

57. Šimun Kursan - Pavao - bandiera Držak (Derzach)

58. Nikola Lasić - Jerolim - Kaštel Lukšić

59. Jakov Leskur - Ivan - bandiera Kapitanović

60. Matija Leskur - Cvitko - bandiera Kapitanović

61. Grgo Lovrić - Mate - Trogir

62. Mate Lovrić - Marko - Rogoznica

63. Dominik Lupieri - Petar - Istra

64. Matija Maleša - Toma - bandiera Kapitanović

65. Cvitko Mamić - Mijo - bandiera Držak (Derzach)

66. Mate Mamić - Ilija - bandiera Držak (Derzach)

67. Šime Mandić - Mihovil - bandiera Držak (Derzach)

68. Ivan Manzin - Ivan - Istra

69. Jadre Marcelić - Marko - Turanj

70. Franjo Marčić - Lovro - bandiera Gulić

71. Antun Markota - Nikola - bandiera Kapitanović

72. Juraj Markota - Ivan - Neretva

73. Antun Marović - Ivan

74. Antun Matulić - Pere - Gorica (kraj Zadra)

75. Ivan Mialić - Ive - Rogoznica

76. Jakov Miloš - Ivan - Imotski

77. Filip Miljević - Juraj - Raštane

78. Nikola Mrdeša - Mate - Sukošan

79. Marko Ninčević - Pavao - bandiera Kapitanović

80. Jakov Nosinović - Martin - Istra

81. Jakov Pajšić - Pero - Vrgorac

82. Nikola Palinić - Petar - Split

83. Franjo Parčić - Marko - bandiera Kapitanović

84. Jakov Pariža - Grgo - bandiera Kapitanović

85. Andrija Pauža - Jakov - bandiera Kapitanović

86. Filip Pauža - Jakov - bandiera Kapitanović

87. Ivo Pavac - Šime - Vrgorac 
88. Matija Perišić - Matija - Buzet

89. Petar Petković - Antun - Knin

90. Cvitko Piteša - Lovro - bandiera Držak (Derzach)

91. Ilija Piteša - Jero - bandiera Držak (Derzach)

92. Andrija Plavšić - Mirko - Drniš

93. Ivan Podrecco - Tadija - Buzet

94. Filip Privačin - Ilija - bandiera Kapitanović

95. Toma Puljić - Josip - Vrgorac

96. Antun Purko - Ivan - bandiera Gulić

97. Stjepan Rađa - Luka - bandiera Kapitanović

98. Nikola Rončević - Dujam - Neretva

99. Toma Salinović - Ivan - Vrgorac

100. Lazo Sladaković - Ivan - Polača

101. Šimun Soda - Ivan - bandiera Držak (Derzach)

102. Mate Sorić - Šime - Ražanci

103. Matija Sorić - Lovre - bandiera Kapitanović

104. Šimun Stipančević - Grgo - Trbounje

105. Šimun Šaić - Toma - bandiera Držak (Derzach)

106. Ivan Šain - Ilija - bandiera Kapitanović

107. Josip Škomelja (Scomeglia) - Matija - bandiera Kapitanović

108. Ive Šolić - Šime - Raštane

109. Toma Tomašić - Antun - Grimalda

110. Dominik Valčić - Gašpar - Istra

111. Petar Vučeta - Stipan - Makarska

112. Šimun Vulin - Mate - bandiera Gulić

113. Gabrijel Žagančić (Zagančić) - Marko - Neretva 
Lovorka ČORALIĆ

Nikola MARKULIN

\section{TROGIR NOBLEMEN MICHIELI VITTURI - HIGHLY RANKED OFFICERS OF THE VENETIAN OVERSEAS LAND UNITS IN THE SECOND HALF OF THE 18TH CENTURY}

\section{SUMMARY}

The central theme of the paper is focused on the part of the military career of the children from the Trogir noble family of Michieli Vitturi : Colonel Vick ( born in 1754), his cousin Lieutenant- Colonel Nikola (born in 1721), and Nikola's son, Captain Jerolim Franjo (born in 1755). They all served as officers of the Venetian overseas land units (Fanti oltramarini) in the last decades and years of the Venetian Republic rule. The work is based on the reading and analysis of material kept in the State Archives in Zadar (the Governors-General of Dalmatia and Albania and the Zanchi Family Holdings), and above all the material from the State Archives in Venice ( the holdings of Inquisitori sopra l'amministrazione dei pubblici ruoli). In the first section of the paper, mostly based on the existing knowledge of historiography, the primary biographical data about the family of Michaeli Vitturi is briefly presented. Then the military careers of Colonel Vick, Lt. Col. Nikola and Captain Jerolim Franjo are discussed in the order corresponding to the height of their military rank. Particular attention is paid to the Venetian registers of their military personnel, and the structure of individual regiments and their pertaining companies is presented.

Furthermore, an essential component of the paper is the comment (given through percentage calculations and graph displays) on the native origin of the company soldiers commanded by the mentioned above members of the Michieli Vitturi's family. Our analysis indicates that - with the expected predominance of soldiers from Dalmatia-members of territorial forces (cernide) were occasionally operating in some of the companies. They, however, were attached to the professional structure of infantry units due to the war turbulence in the north of the Apennine Peninsula at the very end of the Venetian Republic. These were mostly ordinary soldiers from the rural parts of Istria (Buzet region of Karst) and Dalmatia (villages in the Zadar hinterland, the area of Neretva and others). We believe that the study of their names and surnames, thanks to the well-kept registers, are an additional contribution to the knowledge of local communities from the Istrian north to Boka Kotorska. The final section of the paper presents 
several complete lists of military personnel of the troops commanded by three Venetian officers from the Michieli Vitturi family.

Keywords: Michieli Vitturi family, Trogir, Venetian Republic, Venetian overseas infantry, cernide, military history, 18th-century history. 
